\title{
Evaluating a Metric to Predict the Academic and Clinical Success of Master's Students in Speech-Language Pathology
}

Joshua Troche

University of Central Florida, jtroche@ucf.edu

Jacqueline Towson

University of Central Florida, jacqueline.towson@ucf.edu

DOI: doi.org/10.30707/TLCSD2.2Troche

Follow this and additional works at: https://ir.library.illinoisstate.edu/tlcsd

Part of the Communication Sciences and Disorders Commons

\section{Recommended Citation}

Troche, Joshua and Towson, Jacqueline (2018) "Evaluating a Metric to Predict the Academic and Clinical Success of Master's Students in Speech-Language Pathology," Teaching and Learning in Communication Sciences \& Disorders: Vol. 2: Iss. 2, Article 7.

DOI: doi.org/10.30707/TLCSD2.2Troche

Available at: https://ir.library.illinoisstate.edu/tlcsd/vol2/iss2/7

This Scholarship of Teaching and Learning Research is brought to you for free and open access by ISU ReD: Research and eData. It has been accepted for inclusion in Teaching and Learning in Communication Sciences \& Disorders by an authorized editor of ISU ReD: Research and eData. For more information, please contact ISUReD@ilstu.edu. 


\title{
Evaluating a Metric to Predict the Academic and Clinical Success of Master's Students in Speech-Language Pathology
}

\begin{abstract}
Speech-Language Pathology is one of the fastest growing professions in the United States. As such graduate programs have become inundated with applications to their programs in Speech-Language Pathology. Admissions committees often use GPA scores and GRE scores to determine the merit of an undergraduate student for acceptance into their graduate programs. This study examines a metric created to predict the success of graduate students in their academic and clinical work. It was determined that a metric that equally weighs GRE and GPA scores was not particularly predictive of graduate school success. Presented in this work is a new metric that weighs GRE and GPA scores uniquely. This new metric was able to reliably predict the success of students for both academic and clinical coursework in Speech-Language Pathology.
\end{abstract}

\section{Keywords}

Admissions, Graduate School, Success Predictors 
Speech-language pathology is currently one of the fastest growing professions in the United States according to the American Bureau of Labor Statistics. While average job growth is expected to rise at $7 \%$ the next ten years, speech-language pathology is expected to grow at a rate of $21 \%$, almost three times the national average (Bureau of Labor Statistics, 2015). In trend with this growth, graduate programs across the US have been functioning at nearly $100 \%$ capacity since 2010, often over capacity, with total enrollment of nearly 18,000 students across the nation (American Speech-Language-Hearing Association (ASHA), 2015). This growth has led to an increased demand on graduate programs in speech-language pathology over the last few years. According to the ASHA, over 64,000 applications were submitted to master's programs in speech-language pathology during the 2014-2015 academic year (ASHA, 2015). As there are approximately 266 graduate programs in the US, this equates to an average of 300 applications per program per year. Programs typically accept approximately 30 students an admissions cycle (e.g., Fall, Spring, or Summer) meaning that only $10 \%$ of applicants will receive acceptance to a graduate program. It is expected that the number of applications will continue to grow significantly as electronic application submissions make the application process more efficient and allow students to more easily apply to multiple graduate programs. At this time over 120 programs use centralized applications systems such as the Communication Sciences and Disorders Centralized Application Service and the number of programs using the system is expected to grow over time (Communication Sciences and Disorders Centralized Application Service, 2017). The growth of speech-language pathology as a profession and the increase in graduate applications over time has led to an increased burden on programs as they are required to sift through the hundreds of applications to determine which students they should accept for their program.

The question of how to measure a student's success in graduate school is not unique to speechlanguage pathology. Research regarding the "criterion problem" dates back to psychology studies in the late 1970s and early 1980s (Hartnett \& Willingham, 1980; Hirschberg \& Itkin, 1978). Hartnett and Willingham (1980) propose that the definition of graduate student success varies across discipline, but can be generally classified as: (1) traditional (e.g., grades, performance on exams), (2) professional accomplishment (e.g., awards, publications), or (3) "specialty criteria" or outcomes specifically related to critical competencies in a given field (e.g., work samples). Early researchers concluded that it may be difficult to determine what best predicts graduate student success, when the very definition of success has little empirical evidence (Hartnett \& Willingham, 1980; Hirschberg \& Itkin, 1978). In the field of speechlanguage pathology, passing the Praxis exam is one definition of graduate student success as it is required for national certification and often state licensure. According to the Educational Testing Service (ETS), ASHA requires a score of 162 (on a scale of 100-200) on the Praxis exam for speech-language pathology for national certification (ETS, 2017). Based on 12,498 people who took the test during 2016-17, the average score range was 171-185 (median =178), suggesting that most students passed the Praxis exam in that testing interval (ETS, 2016).

Researchers in disciplines related to speech-language pathology, such as health professions, occupational therapy and physical therapy have generally concluded that graduate admissions data should take into consideration a variety of quantitative factors. In the area of occupational therapy, Isenburg and Heater (1994) stated grade point average (GPA) specifically related to in-field coursework and high interview scores corresponded well with student success. However, they cautioned against comparing GPA performance from various institutions. Similarly, in a large study of over 3,000 students across 20 physical therapy programs, researchers used logistic regression to determine if academic difficulty in graduate school (defined as placement on probation, suspension/dismissal from a program, or repeating courses 
due to poor academic performance) and performance on the National Physical Therapy Evaluation (NPTE) could be predicted based on undergraduate GPA (UGPA), GRE quantitative (GRE-Q), or GRE verbal (GRE-V). While there was large variation across programs, UGPA, GRE-Q, and GRE-V were all predictive of academic difficulty, and therefore in turn, potential success (Utzman, Riddle, \& Jewell, 2007a). Likewise, these same three variables were also predictive on success or failure on the NPTE (Utzman, Riddle, \& Jewell, 2007b).

Olivares-Urueta and Williamson (2013) completed a retrospective analysis of graduate students in the field of health professions to evaluate if admissions data could predict students' need for tutoring and the degree of tutoring needed. Using a linear regression model it was determined that GRE-Q, UGPA, GPA related to science coursework, and average number of semester hours taken were significant for predicting the need for tutoring in graduate school. In a review of literature related to health professions (i.e., medical, nursing, physical and occupational therapy), a wide variety of admissions data were analyzed for validity and reliability (Salvatori, 2001). Specifically, the author examined pre-admission academic grades, aptitude tests (e.g., GRE, MCAT, SAT), interviews, written submissions, and letters of reference as they relate to commonly reported outcome measures, such as, academic performance, clinical performance, and licensing examinations. While the author cited a range of predictability across health professions, pre-admission GPA was the single best predictor of academic performance. However, there was a large amount of variance still unaccounted for following this review, suggesting additional qualitative variables (e.g., work experience, interpersonal skills, motivation) may be helpful in determining graduate school success (Salvatori, 2001).

Based on the above review in other related fields, it appears there are a number of factors to consider when reviewing students' application packages for graduate school admissions. The majority of programs in speech-language pathology have chosen to focus on quantitative measures, including UGPA, grades in specific undergraduate courses (e.g., science courses), and Graduate Record Examination (GRE) scores, and qualitative measures, such as recommendation letters and personal essays as their primary means of determining the strength of students for admissions decisions. However, there is limited research on what weight each of these criteria should be given as well as how to quantify all aspects in an equitable way (Baggs, Barnett, \& McCullough, 2015; Forrest \& Naremore, 1998; Halberstam \& Redstone, 2005). With the growing number of applications, it has become necessary to innovate admissions procedures in order to streamline the process to accept the most qualified candidates that will succeed in academic and clinical aspects of graduate school as well as credentialing examinations (i.e., Praxis). One area of innovation can be in the ways we use quantitative measures of a student's success (i.e., GPA, GRE) to predict the student's likelihood of success at the graduate level.

While there have been arguments against the use of highly quantitative models for graduate school admissions, there is literature to support the use of these metrics in graduate school admissions in general (Kuncel, Hezlett, \& Ones, 2001), in speech-language pathology specifically (Baggs et al., 2015; Forrest \& Naremore, 1998; Kjelgaard \& Guarino, 2012; Reed, 2007), and in related professions (e.g., health professions, physical therapy; Burmeister et al., 2014; Isenburg \& Heater, 1994; Olivares-Urueta \& Williamson, 2013; Utzman et al., 2007a, 2007b). In a meta-analysis completed across disciplines from 1,753 independent samples and containing a total of 82,659 students, Kuncel and colleagues (2001) found that GRE scores and UGPA are valid predictors of graduate school performance as measured by first year GPA, 
comprehensive exam results, publication citation counts, and faculty ratings. The GRE was specifically positively correlated with degree completion and research productivity; however, in certain disciplines, GRE subject tests tended to be better predictors than the quantitative, verbal and analytical subsections of the GRE (Kuncel et al., 2001).

In the field of speech-language pathology specifically, several studies have evaluated admissions metrics that may be predictive of graduate student success. In a small study of 30 graduate students, GRE scores did not significantly account for positive graduate performance when a stepwise discriminant analysis was used (Forrest \& Naremore, 1998); however, researchers utilizing larger samples showed contrary results (Baggs et al., 2015; Kjelgaard \& Guarino, 2012; Reed 2007). In a multi-year study of 230 graduate students across four accredited programs in two states, Baggs and colleagues (2015) also used a stepwise discriminant analysis to determine which quantitative measures were predictive of graduate student success as defined by performance on the Praxis exam, graduate GPA, and first semester clinical performance. Results indicated that quantitative measures such as the GREQ, GRE-V, and GRE total (GRE-T) scores, as well as UGPA related to in-field coursework were highly predictive of graduate students' performance on the Praxis exam, while science specific coursework and overall UGPA were not. This study provides additional support for using quantitative metrics (e.g., GPA, GRE-T, GRE-V, GRE-Q) in addition to grades in science specific coursework required by ASHA (biological, physical, and speech-hearing) to make an initial cut in applicants, followed by the use of additional subjective metrics (e.g., letters of recommendation) to determine final admissions decisions. In their study, GRE-T held the highest correlation with Praxis scores, followed by GRE-V, GRE-Q, UGPA, GPA comprised of the last 60 semester hours (L60GPA), speech-hearing science course grades, biological science course grades, and lastly physical science course grades (Baggs et al., 2015). Specifically, GRE-T, GRE-Q, and in-field coursework showed the strongest predictive power (Baggs et al., 2015).

Similarly, Reed (2007) discovered that students at historically black universities (HBUs) who scored greater than 800 on GRE-T (corresponds to approximately 286 on the new form) and had an UGPA greater than 3.0 were five times more likely to pass the Praxis exam. Similar metric results were established by Kjelgaard and Guarino (2012) who included 122 students from several admissions cycles at one New England school. Using a Hotelling's MANOVA, they determined that out-of-field students (i.e., students with an undergraduate degree outside of speech-language pathology) performed better on outcome measures of graduate success (i.e., Praxis, Summative Clinical Evaluation). This finding was directly related to non-SLP undergraduate applicants having higher GRE-V and GRE-Q scores, while in-field applicants had higher GPAs (Kjelgaard \& Guarino, 2012). In a smaller correlational study of 23 students in which GRE scores were not part of the analysis, GPA related to the field, as opposed to overall GPA, was the strongest predictor of both graduate GPA and clinical performance. Additionally, personal essays and letters of recommendation (both subjectively rated) were predictive of graduate GPA (Halberstam \& Redstone, 2005).

The graduate program at the University of Central Florida (UCF) uniquely accepts students three times an academic year (i.e., Fall, Spring, \& Summer). The program has also recently transitioned to the CSDCAS system resulting in an increase in graduate applications. This high volume of applications led the department to attempt to improve the admissions process by creating a metric that would allow for ranking of the students based on their GRE-V scores, GRE-Q scores, Analytical Writing GRE (GRE-W) scores, and their L60GPA, which typically represents in-field coursework (see Figure 1). At the outset of this process, it was unclear how 
strongly to weight each factor, therefore, it was decided as a department to begin by weighting each factor equally. Once several semesters of data could be collected, the program would determine if the metric created was predictive of academic and clinical success.

Admissions data for each semester is collected via CSDCAS. Data is exported to an Excel spreadsheet, which is designed to calculate the total rubric score for each candidate based on the weighting in Figure 1. Within each semester of applicants, the mean and standard deviation (SD) is determined. Candidates that meet or exceed the mean for the given semester are then assigned an individual reviewer to determine the overall adequacy of their application based on the rubric data (i.e., GRE-T, GRE-Q, GRE-V, GRE-W, L60GPA) and qualitative data, made up of the applicant's letter of intent and three letters of recommendation. If a candidate is in question, an additional reviewer is assigned. Offers of acceptance are made to candidates that both meet or exceed the average rubric score and have acceptable qualitative data to support that score.

Admissions Rubric

\begin{tabular}{|c|c|c|c|c|c|c|c|}
\hline Derived Data & $\mathbf{0}$ & 5 & 10 & 15 & 20 & 25 & 30 \\
\hline GRE Verbal & $\begin{array}{c}130-145 \\
1 \% \text { ile- } 25 \% \text { ile }\end{array}$ & $\begin{array}{c}146-147 \\
29 \% \text { ile-33\%ile }\end{array}$ & $\begin{array}{c}148-149 \\
36 \% \text { ile-41\%ile }\end{array}$ & $\begin{array}{c}150 \\
45 \% \text { ile }\end{array}$ & $\begin{array}{c}151-152 \\
50 \% \text { ile-54\%ile }\end{array}$ & $\begin{array}{c}153-154 \\
59 \% \text { ile-63\%ile }\end{array}$ & $\begin{array}{c}155-170 \\
67 \% \text { ile-99\%ile }\end{array}$ \\
\hline $\begin{array}{l}\text { GRE } \\
\text { Quantitative }\end{array}$ & $\begin{array}{c}130-145 \\
1 \% \text { ile-21\%ile }\end{array}$ & $\begin{array}{c}146-147 \\
25 \% \text { ile-28\%ile }\end{array}$ & $\begin{array}{c}148-149 \\
32 \% \text { ile-37\%ile }\end{array}$ & $\begin{array}{c}150 \\
40 \% \text { ile }\end{array}$ & $\begin{array}{c}151-152 \\
45 \% \text { ile- } 48 \% \text { ile }\end{array}$ & $\begin{array}{c}153-154 \\
52 \% \text { ile- } 56 \% \text { ile }\end{array}$ & $\begin{array}{c}155-170 \\
60 \% \text { ile-98\%ile }\end{array}$ \\
\hline $\begin{array}{l}\text { GRE Writing } \\
\text { Analysis }\end{array}$ & $\begin{array}{c}2.5 \\
7 \% \text { ile }\end{array}$ & $\begin{array}{c}3 \\
15 \% \text { ile }\end{array}$ & $\begin{array}{c}3.5 \\
38 \% \text { ile }\end{array}$ & $\begin{array}{c}4 \\
56 \% \text { ile }\end{array}$ & $\begin{array}{c}4.5 \\
80 \% \text { ile }\end{array}$ & $\begin{array}{c}5 \\
93 \% \text { ile }\end{array}$ & $\begin{array}{c}5.5-6 \\
98 \% \text { ile-99\%ile }\end{array}$ \\
\hline $\begin{array}{l}\text { GPA Last } 60 \\
\text { Hours of the } \\
\text { undergraduate } \\
\text { degree }\end{array}$ & Below 3.0 & $3.0-3.19$ & $3.2-3.39$ & $3.4-3.59$ & $3.6-3.79$ & 3.8-3.99 & 4.0 \\
\hline
\end{tabular}

Figure 1. Breakdown of our predictive metric.

The purpose of this paper was to outline the procedure and analysis of the initial metric (i.e., equal weighting of all quantitative admissions criteria) and evaluate whether the metric could successfully predict a student's academic and clinical success in the graduate program as measured by current GPA in the graduate program and clinical measures. The second goal was to determine the ideal weighting of these same quantitative factors for the predictive metric for use in future admission cycles. We also were interested in exploring the admissions data for top performing students in the Master's program and students on remediation plans. The academic and clinical data of four cohorts who were evaluated for admissions to a graduate program in speech-language pathology using the initial metric (i.e., equal weighting of all factors) were analyzed. Input based on prior research in speech-language pathology and related fields was used to validate the results.

\section{Methods}

Sample. The academic and clinical data for four cohorts (i.e., groups of students admitted in unique semesters) of graduate students in our speech-language pathology graduate program were gathered for analyses. All four of these cohorts were admitted using the predictive metric. 
The total number of students in these four cohorts was 135 students. Complete academic data was available for all 135 of the students and complete clinic coursework data for 90 of the 135 students (a portion of the students had yet to begin clinical coursework). The demographic details of the sample can be found in Table 1 .

Table 1

Demographic Information of Students in the Graduate Cohorts

\begin{tabular}{|c|c|c|c|c|}
\hline \multirow[t]{2}{*}{ Cohort } & \multicolumn{2}{|c|}{ Race } & \multicolumn{2}{|c|}{ Ethnicity } \\
\hline & White & Non-White & Hispanic & Non-Hispanic \\
\hline Cohort 1 & 37 & 1 & 5 & 33 \\
\hline Cohort 2 & 29 & 9 & 11 & 27 \\
\hline Cohort 3 & 26 & 5 & 7 & 24 \\
\hline Cohort 4 & 25 & 3 & 7 & 21 \\
\hline \multirow[t]{3}{*}{ Total } & 117 & 18 & 30 & 105 \\
\hline & \multicolumn{2}{|c|}{ Gender } & \multicolumn{2}{|c|}{ Major } \\
\hline & Male & Female & CSD & Other \\
\hline Cohort 1 & 3 & 35 & 30 & 8 \\
\hline Cohort 2 & 2 & 36 & 32 & 6 \\
\hline Cohort 3 & 0 & 31 & 26 & 5 \\
\hline Cohort 4 & 3 & 25 & 22 & 6 \\
\hline Total & 8 & 127 & 110 & 25 \\
\hline
\end{tabular}

Note: $\mathrm{CSD}=$ Communication Sciences and Disorders major

Predictors. The elements of the predictive metric were all three components of the GRE: GREQ, GRE-V, GRE-W and the L60GPA as this can capture both in-field coursework but also the point in which students often become more focused on their overall educational and career path. UGPA was also included to determine if this was a better predictor as compared to L60GPA. While prior research studies support the use of these specific quantitative predictors, these were measures currently in use at the University of Central Florida and therefore the ones available for analysis.

Outcome Measures.

Academic measure. The academic measure that was collected was students' current cumulative Master's level GPA. This was the GPA for all coursework the student had taken at the graduate level to date. Sample plan of study for the graduate program be seen in Figure 2. This measure varied by cohort, as some students may have completed one semester while others had completed up to four. A one-way ANOVA was performed to determine if there were significant differences across cohorts for Master's GPA. There was no main effect for cohort on Master's GPA $[F(3,131)=1.40, p=.25]$.

Clinical coursework measures. The measures of clinical success were twofold. One measure was the Clinical Checkpoint data and the other was the Clinical Skill Acquisition Rubric (CSAR) scores.

The Clinical Checkpoint is an examination of the student's clinical skills at the halfway point of their studies. The students are given a simulated case and work with standardized patients and caregivers. The students must effectively perform a case history, evaluate the patient, 
complete an appropriate plan of care, and deliver diagnostic information to a parent or caregiver. The students are graded on their ability to perform the tasks above appropriately as scored by clinical educators. The process is similar to competencies a Master's student might take at the end of their program as a final examination for their degree. It is an opportunity for the program to measure their ability to independently diagnose, create a treatment plan, and interact with standardized patients. As this measure has been recently implemented in the graduate program, there is no validity or reliability data currently available.

\section{Sample Plan of Study}

\section{Semester 1}

Articulation/Phonological Disorders

Voice Disorders

Language Disorders in Children and Adolescents

Foundations of Clinical Practice: Level I

\section{Semester 2}

Fluency Disorders

Aphasia and Related Disorders

Augmentative and Alternative Communication

Systems

Foundations of Clinical Practice: Level II

Foundations of Clinical Practice: Level II

Application

\section{Semester 3}

Aural Habilitation/Rehabilitation

Feeding and Swallowing Disorders

Research in Communicative Disorders

Foundations of Clinical Practice: Level III

Foundations of Clinical Practice: Level|

III Application

Clinical Practice in Differential Diagnosis in Speech

and Language Pathology

\section{Semester 4}

Motor Speech Disorders in Adults and Children Assessment and Management of Culturally and

Linguistically Diverse Populations

Clinical Practice: Level I

Elective

\section{Semester 5}

Clinical Practice: Level II

Elective

Elective

\section{Semester 6}

Clinical Practice: Level III

Figure 2. Sample plan of study for the graduate program

The CSAR is a standardized measure that is completed by clinical supervisors in order to track student progress in their clinical rotations (Resnick, Whiteside, \& Kong, 2014). The measure tracks students' treatment planning and interpretation skills as well as their diagnostic skills. The measure was developed at the University of Central Florida and targets skills dictated from the ASHA standards. Students are scored across 28 key elements related to the clinical skills of diagnosis, treatment, and professionalism. Each of these 28 key elements are rated using scores from 1-7 which were inspired by the Functional Independent Measurement scores (Ottenbacher, Hsu, Granger, \& Fiedler, 1996). In other words, the score for the element corresponds to the level of assistance required from the clinical instructor for the key element. The scale offers a rubric for scoring (see Appendix A) which allows for good inter-rater reliability $(r=.713)$ across clinical instructors. The measure has also shown acceptable validity when compared to the older KASA measures $(r=.646)$.

Remediation plans. The graduate program at the University of Central Florida utilizes remediation plans for graduate students identified as not meeting one or more of the ASHA standards, previously identified by the Knowledge and Skills Acquisition (KASA) form (Council for Clinical Certification in Audiology and Speech-Language Pathology of the American Speech-Language-Hearing Association, 2013). These standards are embedded 
throughout the academic and clinical course requirements and addressed through course objectives, assignments, and examinations. When a student is identified as requiring a remediation plan, the ASHA standard(s) in question are listed and a plan devised with specific outcomes and timelines to determine when the standard(s) are satisfied. Failure to complete these outcomes may result in delay in advancement or dismissal from the program.

Analyses. The goal of this study was to determine the strength of our original metric to predict academic and clinical success. For the academic and clinical coursework measures, we compared the predictive metric to its individual components. Three regressions in total were performed for each outcome measure: a regression with the original metric as a predictor, a regression with the individual GRE scores (i.e., GRE-Q, GRE-V, GRE-W) and L60GPA as predictors, and a regression with the individual GRE scores and UGPA as predictors (see Table 2 ). The models were built in this way to determine if: (1) the entire metric was more predictive than its individual components, (2) L60GPA was a better predictor than UGPA, and (3) the correct weighting for the individual metric components resulted in a new metric that was more strongly predictive of academic and clinical success.

Secondary analyses. A secondary analysis was performed that focused on students with remediation plans (see above for details on remediation plans). Mann Whitney U nonparametric tests were run to determine if students on remediation plans had significant differences in their predictors (e.g., GRE-T, L60GPA) compared to those students who were not on remediation plans. Nonparametric statistics were used as sample sizes were small $(n=$ 11) and non-normal.

Another secondary analysis was performed comparing students that performed a SD above the mean and a SD below the mean for both academic and clinical coursework. For this study, a proxy measure of academic and clinical coursework success was created by z-transforming the outcome measures (i.e., Master's GPA, Clinical Checkpoint, and CSAR) and averaging them together to create a single score. Students were then stratified by those who were one SD above the mean for this new measure and one SD below the mean. A Mann Whitney U nonparametric test was performed for all individual predictors (e.g., GRE-T, L60GPA) to compare students performing one SD above and one SD below the mean in academic and clinical coursework in these predictors.

Weighting of new metric. Beta-weights were used to determine the weighting of the individual components for the new predictive metric as they represent the unique strength of a predictor while controlling for the other predictors in the model (Piedmont, 2014). The goal was for the metric to be predictive for both academic and clinical coursework, therefore, weighting of the beta-weights for the new predictive metric also took into account the strength of the predictiveness of the model (i.e., r). A detailed explanation of the process can be seen below in the results section.

\section{Results}

Regression. Analysis of the regression data revealed that the original predictive metric was less predictive than the models that input either UGPA or L60GPA and GRE scores individually for all outcome measures (see Table 2). It was also revealed that L60GPA was more predictive than UGPA overall. Of the best fit models for each outcome measure (i.e., Master's GPA = Model 3; Clinical Checkpoint $=$ Model 3; CSAR $=$ Model 2), only the models for Master's GPA $[F(4,118)=6.036, p<.05]$ and Clinical Checkpoint were significant 
$[F(4,86)=2.736, p<.05]$. We will describe these significant best fits models throughout the manuscript as Master's GPA Model 3 and Clinical Checkpoint Model 3. Of the individual predictors in the best fit models, L60GPA was the strongest for both Master's GPA $(\beta=.354)$ and Clinical Checkpoint $(\beta=.312)$. The next strongest predictor for both Master's GPA and Clinical Checkpoint was the GRE-Q scores (Master's GPA $\beta=.159$; Clinical Checkpoint $(\beta=.221)$.

\section{Table 2.}

Regression Table for Academic and Clinical Predictors

\begin{tabular}{|c|c|c|c|c|c|c|}
\hline \multirow[b]{2}{*}{ Variable } & \multicolumn{3}{|c|}{ Master's GPA } & \multicolumn{3}{|c|}{ Clinical Checkpoint } \\
\hline & Model $1 \beta$ & Model $2 \beta$ & Model $3 \beta$ & Model $1 \beta$ & Model $2 \beta$ & Model $3 \beta$ \\
\hline Metric & 0.28 & & & -0.021 & & \\
\hline GRE-V & & 0.036 & 0.049 & & -0.072 & -0.032 \\
\hline GRE-Q & & 0.158 & 0.159 & & 0.176 & 0.221 \\
\hline GRE-W & & 0.05 & 0.042 & & 0.137 & 0.162 \\
\hline $\begin{array}{l}\text { L60GPA } \\
\text { Cum }\end{array}$ & & & 0.354 & & & 0.312 \\
\hline GPA & & 0.309 & & & 0.142 & \\
\hline $\mathrm{R}$ & 0.28 & 0.383 & 0.412 & 0.021 & 0.28 & 0.383 \\
\hline$\Delta \mathrm{R}$ & & 0.103 & 0.029 & & 0.259 & 0.103 \\
\hline Variable & Model $1 \beta$ & $\begin{array}{c}\text { CSAR } \\
\text { Model } 2 \beta \\
\end{array}$ & Model $3 \beta$ & & & \\
\hline Metric & -0.125 & & & & & \\
\hline GRE-V & & -0.229 & -0.122 & & & \\
\hline GRE-Q & & 0.04 & -0.012 & & & \\
\hline GRE-W & & -0.009 & -0.119 & & & \\
\hline $\begin{array}{l}\text { L60GPA } \\
\text { Cum }\end{array}$ & & & 0.055 & & & \\
\hline GPA & & -0.137 & & & & \\
\hline $\mathrm{R}$ & 0.125 & 0.235 & 0.21 & & & \\
\hline$\Delta \mathrm{R}$ & 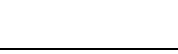 & 0.11 & -0.025 & & & \\
\hline
\end{tabular}

Secondary Analyses. For our secondary analyses, we focused on the group of students in the cohort that had been placed on remediation plans for either academic or clinical coursework difficulties. A Mann-Whitney test was completed and revealed that students (See Table 3) on remediation plans had significantly higher GRE-V scores while having significantly lower L60GPA scores (see Table 4).

Another secondary analysis focused on students who were performing one SD above and below the mean for both academic and clinical coursework (see Table 5). It was determined that there were significant differences in L60GPA and GRE-Q with both being higher in top performing students (Table 6). 
Table 3.

Demographics of Students on Remediation Plans

\begin{tabular}{cccc}
\hline & Race & \multicolumn{2}{c}{ Ethnicity } \\
\hline White & Non-White & Hispanic & Non-Hispanic \\
10 & 1 & 2 & 9 \\
\hline \multicolumn{2}{c}{ Gender } & \multicolumn{2}{c}{ Major } \\
\hline Male & Female & CSD & Other \\
4 & 7 & 10 & 1
\end{tabular}

Note: $\mathrm{CSD}=$ Communication Sciences and Disorders major

Table 4.

Mann-Whitney U Table for Students on Remediation Plans

\begin{tabular}{|c|c|c|c|c|c|c|c|c|c|c|c|}
\hline & & \multicolumn{5}{|c|}{ Verbal GRE } & \multicolumn{5}{|c|}{ Quant GRE } \\
\hline & & M & MD & $\mathrm{U}$ & $\mathrm{z}$ & $\mathrm{p}$ & M & $\mathrm{MD}$ & $\mathrm{U}$ & $\mathrm{z}$ & $\mathrm{p}$ \\
\hline \multirow[t]{4}{*}{ Rem } & $\mathrm{Y}$ & 157.00 & 4.54 & 986.00 & 2.45 & 0.01 & 147.64 & -0.53 & 726.00 & 0.36 & 0.72 \\
\hline & $\mathrm{N}$ & 152.46 & & & & & 148.17 & & & & \\
\hline & & \multicolumn{5}{|c|}{ Writing GRE } & \multicolumn{5}{|c|}{ L60GPA } \\
\hline & & M & MD & $\mathrm{U}$ & $\mathrm{z}$ & $\mathrm{p}$ & M & $\mathrm{MD}$ & $\mathrm{U}$ & $\mathrm{z}$ & $\mathrm{p}$ \\
\hline \multirow[t]{2}{*}{ Rem } & $\mathrm{Y}$ & 3.77 & -0.18 & 591.00 & -0.77 & 0.44 & 3.41 & -0.27 & 393.50 & -2.34 & 0.02 \\
\hline & $\mathrm{N}$ & 3.95 & & & & & 3.68 & & & & \\
\hline
\end{tabular}

Notes: Rem=Remediation Plan; MD=Mean Difference; U=Mann-Whitney U statistic

Table 5.

Demographics for Students Performing a Standard Deviation Above and Below the Mean

\begin{tabular}{|c|c|c|c|c|}
\hline & \multicolumn{2}{|c|}{ Race } & \multicolumn{2}{|c|}{ Ethnicity } \\
\hline & White & Non-White & Hispanic & Non-Hispanic \\
\hline $1 \mathrm{SD}$ & 12 & 2 & 1 & 13 \\
\hline \multirow[t]{3}{*}{$-1 \mathrm{SD}$} & 13 & 0 & 3 & 10 \\
\hline & \multicolumn{2}{|c|}{ Gender } & \multicolumn{2}{|c|}{ Major } \\
\hline & Male & Female & CSD & Other \\
\hline $1 \mathrm{SD}$ & 2 & 12 & 13 & 1 \\
\hline$-1 S D$ & 0 & 13 & 12 & 1 \\
\hline
\end{tabular}

Note: $\mathrm{CSD}=$ Communication Sciences and Disorders major 
Table 6.

Mann-Whitney U Table for Students Performing a Standard Deviation Above and Below the Mean

\begin{tabular}{ccccccccccc}
\hline \multicolumn{1}{c}{ Verbal GRE } & \multicolumn{1}{c}{ Quant GRE } \\
\hline & $\mathrm{M}$ & $\mathrm{MD}$ & $\mathrm{U}$ & $\mathrm{z}$ & $\mathrm{p}$ & $\mathrm{M}$ & $\mathrm{MD}$ & $\mathrm{U}$ & $\mathrm{z}$ & $\mathrm{p}$ \\
1 SD & 152.91 & -0.14 & 302.50 & -1.17 & 0.24 & 148.92 & 2.68 & 233.00 & -2.28 & 0.02 \\
$-1 \mathrm{SD}$ & 153.05 & \multicolumn{1}{c}{ Writing GRE } & & & \multicolumn{7}{c}{ L60GPA } \\
\hline \multicolumn{1}{c}{} & $\mathrm{M}$ & $\mathrm{MD}$ & $\mathrm{U}$ & $\mathrm{z}$ & $\mathrm{p}$ & $\mathrm{M}$ & $\mathrm{MD}$ & $\mathrm{U}$ & $\mathrm{z}$ & $\mathrm{p}$ \\
\hline 1 SD & 4.09 & 0.21 & 364.50 & -0.05 & 0.96 & 3.71 & 0.24 & 148.50 & -3.73 & 0.01 \\
$-1 \mathrm{SD}$ & 3.88 & & & & & 3.47 & & & & \\
\hline
\end{tabular}

Notes: $1 \mathrm{SD}=1$ Standard Deviation above; $-1 \mathrm{SD}=1$ Standard Deviation below; $\mathrm{MD}=$ Mean Difference; U=Mann-Whitney U statistic

New Weighted Rubric. A new weighted rubric was created using the beta-weights from Master's GPA Model 3 and Clinical Checkpoint Model 3. The CSAR data was not included as no models were found to be significant for this outcome measure. The goal was to create a measure that could simultaneously be predictive for academic coursework and clinical coursework. For Master's GPA Model 3 and Clinical Checkpoint Model 3, beta-weights were summed (e.g., Master's GPA = L60GPA $\beta(.354)+$ GRE-W(.042) + GRE-Q(.159) + GRE$\mathrm{V}(.049)=.604)$ and then each predictor was divided by the sum to get a percentage of the sum for each predictor (e.g., L60GPA $\beta(.354)$ /Master's GPA $\beta$ Total(.604) = .586). The Pearson correlation was then used to determine the weighting for each beta-weight across Master's GPA Model 3 and Clinical Checkpoint Model 3. The Pearson correlations of both models were summed (i.e., Master's GPA(.412) + Clinic Checkpoint $(.383)=.795)$ and then divided by this sum (e.g., Master's GPA(.412)/rTotal $(.795)=.518)$. Next, the Pearson correlation percentage of the corresponding model was multiplied by the beta-weight percentage of the individual predictors from that model (e.g. rPercentageMaster'sGPA(.518)* L60GPABeta-weight(.586) $=.303)$. Finally, this number was added to the corresponding predictor in the other model (e.g.,.303 $+.206=50.9)$ to create the new weighting. See Table 7 for the weightings for all four predictors.

\section{Table 7.}

New Weighted Rubric

\begin{tabular}{lr}
\hline & $\%$ Weight \\
\hline Verbal GRE & 6.3166 \\
Quant GRE & 28.2762 \\
Writing GRE & 14.3746 \\
L60 GRE & 51.0326 \\
\hline
\end{tabular}

A regression was then performed to determine the difference in fit between the new metric and Master's GPA Model 3 and Clinical Checkpoint Model 3 (Table 8). The models with the new metric showed a slight reduction in predictive power from the Master's GPA Model 3 and Clinical Checkpoint Model 3. The models with the new metric, however, remained significant Master's GPA $[F(1,121)=19.407, p<.05]$; Clinical Checkpoint $[F(1,89)=6.231, p<.05]$ and a loss of predictive power was to be expected in order to create a metric that was both predictive for academic and clinical measures simultaneously. 
Table 8.

Regression Table for Best Fit Model vs New Weighted Rubric

Master's GPA Clinical Checkpoint

\begin{tabular}{lrrrr} 
Variable & Model $3 \beta$ & Model $4 \beta$ & Model $3 \beta$ & Model $4 \beta$ \\
\hline Verbal GRE & 0.049 & & -0.032 & \\
Quant GRE & 0.159 & & 0.221 & \\
Writing GRE & 0.042 & & 0.162 & \\
L60GPA & 0.354 & & 0.312 & \\
New Rubric & & 0.372 & & 0.318 \\
R & 0.412 & 0.372 & 0.383 & 0.318 \\
$\Delta \mathrm{R}$ & & -0.04 & & -0.065
\end{tabular}

Note: $\Delta \mathrm{R}=$ Change in $\mathrm{R}$ from previous model.

\section{Discussion}

Graduate programs in speech-language pathology and related fields across the US use quantitative admissions data as a first step in the review process (e.g., Forrest \& Naremore, 1998; Halberstam \& Redstone, 2005; Kuncel et al. 2001; Polovoy, 2014; Utzman et al., 2007a, 2007b). However, according to Tekieli Koay and colleagues (2016) GPA and GRE data across the 260 US programs lack variability. It is important to develop a metric that not only evaluates this quantitative data, but weights it according to the ability to predict academic and clinical success in graduate programs. The purpose of this study was to both examine the utility of a weighted predictive metric already in place and to determine the ideal weighting of quantitative factors for use in future admission cycles for graduate students in one speech-language pathology program in the Southeastern US.

Initial analysis examining the metric originally used by the University of Central Florida, where all factors (i.e., UGPA, GRE-V, GRE-Q, GRE-W) were weighted equally, did not predict graduate student success as measured by academic (i.e., Master's GPA) or clinical (i.e., CSAR, clinical checkpoint) measures. However, results from this study did support previous studies of larger samples of students for the use of GRE scores and UGPA in graduate admissions criteria (Baggs et al., 2015; Kjelgaard \& Guarino, 2012; Reed 2007) as significant best fits were obtained for both the Master's GPA and the clinical checkpoint models using L60GPA and GRE-Q. While considering each factor equally was not predictive of future success in graduate school, a differential weighting of each factor was predictive. Specifically, this data showed that L60GPA was the strongest predictor for both Master's GPA and the clinical checkpoint that occurs mid-program (i.e., end of semester three), followed by GRE-Q, GREW, and GRE-V. Specifically, L60GPA was predictive for $51 \%$ of the student's graduate GPA and clinical performance as measured by the clinical checkpoint. Scores on the GRE-Total accounted for the remaining 49\%, with the GRE-Q showing the most predictive ability at $28 \%$, the GRE-W second at $14 \%$ and the GRE-V showing the least predictive power at $6 \%$ (see Table 7). While the ranked order of these variables was the same for Master's GPA and the clinical checkpoint, the model was overall more predictive for GPA. This result is consistent with prior research showing that admissions materials are more predictive of graduate student's performance in coursework (i.e., GPA) than to faculty scored clinical metrics (Halberstam \& Redstone, 2005). Similiar to work by Halberstam and Redstone (2005) in speech-language pathology and Isenburg and Heater (1994) in occupational therapy, the model revealed 
L60GPA, representative of in-field coursework, was more predictive overall than the cumulative GPA.

The outcome variables for which the models were significant in this study were limited to Master's GPA and a clinical checkpoint. However, it could be inferred that students in this sample scoring higher on the GRE-T, GRE-Q, and with higher L60GPA may also experience greater success on additional outcome measures, such as the Praxis exam. This would be consistent with prior research showing that GRE-T, as well as the individual components of the GRE and L60GPA are predictive of success on the Praxis in the field of speech-language pathology (Baggs et al., 2015; Reed, 2007) and the national certification exam for physical therapy (Utzman et al., 2007b). This supports the idea of weighting these variables for the purposes of graduate admissions to raise the probability of student success in both the graduate program, as well as in outcomes on the Praxis. While some of the regression models were predictive of Master's GPA and the clinical checkpoint, surprisingly, none of the models were predictive for the CSAR. Therefore, the CSAR was not included in the calculation of the new metric. Future analysis validating the new metric should include the CSAR as an outcome variable to ensure admissions data can successfully account for student success across multiple indicators.

The secondary analysis also strongly indicates that the data should be differentially weighted. The fact that students on remediation plans were more likely to have lower L60GPA and higher GRE-V scores suggests that the GRE-V scores were given too much weight, while not weighing L60GPA high enough. This was also the case when looking at students who performed one SD above and one SD below the mean. Those higher achieving students performed significantly better on L60GPA and GRE-Q. Consistent with prior research in physical therapy where GRE-V and GRE-Q accounted for students with "academic difficulty", these variables should and have been weighed more heavily in the original (equally weighted) metric we describe above (Utzman et al., 2007a).

While this study did not consider student application materials outside of those which are readily quantifiable, it may be viable to consider applying a quantitative rating to items such as letters of intent, letters of recommendation, and prior experience with research. When evaluated in earlier studies, personal essays and letters of recommendation were given subjective ratings and found to be predictive of graduate GPA (Halberstam \& Redstone, 2005). The metric established by Halberstam and Redstone (2005) was highly reliable (IRR coefficients of 0.9 or higher) suggesting that faculty could consistently evaluate applicants' materials and add further depth to the admissions process. Concerns by the authors in this study relate to the certainty that students are composing their own letters of intent, and the vast variability observed in how faculty write letters of recommendation. Future studies should evaluate the combined predictive ability of both quantitative and subjective aspects of graduate applicant materials.

This study was an initial exploration to determine a reliable metric for quantitative admissions data for students applying to one graduate school in speech-language pathology. Based on multiple analyses, a differentially weighted metric is recommended for future admissions cycles for this program (see Table 7). As this new metric is applied, data will continue to be evaluated to determine if graduate student success can be better predicted using quantitative data such as the GRE and UGPA. However, future research should incorporate the consideration of additional input variables (i.e., letters of recommendation) as well as 
additional outcome measures that capture student success (i.e., Praxis scores, cumulative graduate GPA).

Limitations. This study presents with several limitations which should be brought forth. First, the data represents one graduate program from one region in the US and may not be representative of all graduate programs in CSD. Therefore, the findings may be specific to the program data evaluated. Secondly, this study is based solely on students accepted to a graduate program. If data from students not admitted could be included, the model may result in different weighting of the variables. This is important to note, as students whose data are not included are representative both of students that did not meet this university's criteria, but also of those who were offered admittance and declined. Related to this issue is the limited variability in the quantitative data examined. Similar to Halberstam and Redstone (2005), the data in this study related to GPA (either UGPA or L60GPA) was most often greater than 3.0. It is also difficult to account for the variability students may experience in undergraduate coursework across institutions as cautioned by Isenburg and Heater (1994). Finally, data in this analysis is representative of four unique cohorts of students and is taken at different time points in their program (i.e., end of first, second, third, or fourth semester). While all students follow a lockstep model for coursework, if all data represented the same number of credit hours for the Master's GPA, the results may have been different. Additionally, data was only available for the clinical checkpoint and CSAR for students that have completed their third semester $(n=$ 90). Future analyses should include student data which is more complete, including additional outcome measures, such as the Praxis and final graduate GPA. Finally, while we provide reliability and validity data for the CSAR, which was not able to be predicted, there is not yet the same data available for the clinical checkpoint, which was more recently implemented at this university.

Conclusion. This study contributes to the ongoing quandary faced by institutions housing graduate programs in communication sciences and disorders related to admissions criteria by developing a weighted predictive metric. While consistent with prior literature suggesting the predictive nature of GPA specifically that related to in-field coursework and GRE scores, this study adds to the literature by suggesting a weighted system for the admission variables. Specifically, admissions criteria for this university and others with similar demographics of student applicants should consider use of the differentially weighted metric as suggested in this manuscript. The utility of the metric should allow for more precision in the selection of graduate candidates, and in turn, the increased success of those students in a graduate program.

\section{References}

American Speech-Language-Hearing Association. (2015). Communication sciences and disorders education trend data. Retrieved from http://www.asha.org/uploadedFiles/ Trend-Report-AYs-2010-2011-through-2014-2015.pdf.

American Speech-Language-Hearing Association. (2017). ASHA EdFind. Retrieved from http://www.asha.org/edfind/

Baggs, T., Barnett, D., \& McCullough, K. (2015). The value of traditional cognitive variables for predicting performance in graduate speech-language pathology programs. Journal of Allied Health, 44, 10-16. 
Bureau of Labor Statistics. (2015). Occupational Outlook Handbook: Speech-Language Pathologists: 2016-2017. Retrieved from https://www.bls.gov/ooh/healthcare/speechlanguage-pathologists.htm

Burmeister, J., McSpadden, E., Rakowski, J., Nalichowski, A., Yudelev, M., \& Snyder, M. (2014). Correlation of admissions statistics to graduate student success in medical physics. Journal of Applied Clinical Medical Physics, 15(1), 375-385.

Communication Sciences and Disorders Centralized Application Service. (2017). CSDCAS participating programs list for the 2017-2018 application cycle. Retrieved from https://portal.csdcas.org/csdcasHelpPages/participating-programs-2/

Council for Clinical Certification in Audiology and Speech-Language Pathology of the American Speech-Language-Hearing Association. (2013). 2014 standards for the certificate of clinical competence in speech-language pathology. Retrieved from http://www.asha.org/Certification/2014-Speech-Language-Pathology-CertificationStandards/.

Educational Testing Service. (2016). Understanding your Praxis scores 2016-17. Retrieved from https://www.ets.org/s/praxis/pdf/uyps_1617.pdf

Educational Testing Service. (2017). American Speech-Language-Hearing Association (ASHA) Test Requirements. Retrieved from https://www.ets.org/praxis/asha/ requirementsForrest, K., \& Naremore, R. C. (1998). Analysis of criteria for graduate admissions in speech-language pathology: Predictive utility of application materials. American Journal of Speech-Language Pathology, 7(4), 57-61.

Halberstam, B., \& Redstone, F. (2005). The predictive value of admissions materials on objective and subjective measures of graduate school performance in speech-language pathology. Journal of Higher Education Policy and Management, 27, 261-272.

Hartnett, R. T., \& Willingham, W. W. (1980). The criterion problem: What measure of success in graduate education?. Applied Psychological Measurement, 4, 281-291.

Hirschberg, N., \& Itkin, S. (1978). Graduate student success in psychology. American Psychologist, 33, 1083.

Isenburg, B. D., \& Heater, S. L. (1994). Professionalization of the field: how can educational programs identify the best applicants?. American Journal of Occupational Therapy, $48,758-759$.

Kjelgaard, M. M., \& Guarino, A. J. (2012). Assessing clinical and academic performance in a master's level speech language pathology program: A path analysis. Creative Education, 3, 145-148.

Kuncel, N. R., Hezlett, S. A., \& Ones, D. S. (2001). A comprehensive meta-analysis of the predictive validity of the graduate record examinations: Implications for graduate student selection and performance. Psychological Bulletin, 127, 162-181.

Olivares-Urueta, M., \& Williamson, J. W. (2013). Pre-admission factors and utilization of tutoring services in health professions educational programs. Journal of Allied Health, $42,74-78$. 
Ottenbacher, K. J., Hsu, Y., Granger, C. V., \& Fiedler, R. C. (1996). The reliability of the functional independence measure: A quantitative review. Archives of Physical Medicine and Rehabilitation, 77, 1226-1232.

Piedmont, R. L. (2014). Beta weights. In A. C. Michalos (Ed.), Encyclopedia of Quality of Life and Well-Being Research (pp. 381-382). Dordrecht, NL: Springer Netherlands.

Polovoy, C. (2014). Craft a stand-out application. The ASHA Leader, 19, 54-55.

Reed, H. C. (2007). Identifying the admissions criteria that predict success in a master's-level communicative sciences and disorders program at a historically black university. $E$ Journal for Black and Other Ethnic Group Research and Practices in Communication Sciences and Disorders, 3(2), 28-45.

Resnick, P., Whiteside, J., \& Kong, A. (2014, November). Introducing the Clinical Skill Acquisition Rubric (CSAR): A new objective measure of clinical skill acquisition. Paper presented at the meeting of the American Speech-Language-Hearing Association, Orlando, FL.

Salvatori, P. (2001). Reliability and validity of admissions tools used to select students for the health professions. Advances in Health Sciences Education, 6, 159-175.

Tekieli Koay, M. E., Lass, N. J., Parrill, M., Naeser, D., Babin, K., Bayer, O., ... \& Kerwood, S. (2016). Availability of pre-admission information to prospective graduate students in speech-language pathology. Journal of Higher Education Policy and Management, $38,465-476$.

Utzman, R. R., Riddle, D. L., \& Jewell, D. V. (2007a). Use of demographic and quantitative admissions data to predict academic difficulty among professional physical therapist students. Physical Therapy, 87, 1164-1180.

Utzman, R. R., Riddle, D. L., \& Jewell, D. V. (2007b). Use of demographic and quantitative admissions data to predict performance on the national physical therapy examination. Physical Therapy, 87, 1181-1193. 


\section{Appendix A}

\section{Rubric for CSAR Measure}

\begin{tabular}{|c|c|c|c|c|c|c|c|}
\hline Key Elements & Level I & Level II & Level III & Level IV & Level V & Level VI & Level VII \\
\hline Modes of Acquisition & \multicolumn{4}{|c|}{ Academic Lab, Online Modules, Simulation, UCF Clinic } & & & \\
\hline $\begin{array}{c}\text { Learning Objectives/ } \\
\text { Benchmarks }\end{array}$ & $\begin{array}{c}\text { Dependent on Clinical } \\
\text { Educator }\end{array}$ & $\begin{array}{l}\text { Maximum assistance } \\
\text { provided by Clinical } \\
\text { Educator }\end{array}$ & $\begin{array}{c}\text { Moderate assistance } \\
\text { provided by Clinical } \\
\text { Educator }\end{array}$ & $\begin{array}{c}\text { Minimal assistance } \\
\text { provided by Clinical } \\
\text { Educator }\end{array}$ & $\begin{array}{l}\text { Semi-Independent } \\
\text { from Clinical Educator }\end{array}$ & $\begin{array}{l}\text { Independent from } \\
\text { Clinical Educator } \\
\text { with consultative } \\
\text { guidance }\end{array}$ & $\begin{array}{l}\text { Independent from } \\
\text { Clinical Educator }\end{array}$ \\
\hline Level of Expertise & $100 \%$ assistance & $75-50 \%$ assistance & $50-25 \%$ assistance & $<25 \%$ assistance & $20-10 \%$ assistance & $10-0 \%$ assistance & $\begin{array}{l}\text { Student initiated } \\
\text { assistance }\end{array}$ \\
\hline \multicolumn{8}{|c|}{$\begin{array}{l}\text { TREATMENT } \\
\text { Planning }\end{array}$} \\
\hline $\begin{array}{l}\text { 1. Demonstrates ability } \\
\text { to review case file and } \\
\text { abstract relevant } \\
\text { information needed to } \\
\text { develop a plan of care. } \\
\text { Self-Evaluation } \\
\text { Midterm } \\
\text { Final }\end{array}$ & $\begin{array}{l}\text { Inaccurate \& Inefficient } \\
\text { Student is not familiar } \\
\text { with file contents and is } \\
\text { unable to find relevant } \\
\text { information regarding } \\
\text { diagnosis, prior level of } \\
\text { function, medical/social } \\
\text { history, medical reports } \\
\text { including radiology } \\
\text { reports, reports regarding } \\
\text { prior treatment. Student is } \\
\text { unable to determine } \\
\text { current function based on } \\
\text { the file. Constant } \\
\text { assistance is required. }\end{array}$ & \begin{tabular}{l}
\multicolumn{1}{c}{ Partially Accurate } \\
Student may be able to \\
identify one or more \\
elements of relevant \\
information in the chart \\
but is unable to \\
understand the \\
application/relevance to \\
the case without \\
directive. The student \\
needs specific \\
instruction the majority \\
of the time.
\end{tabular} & $\begin{array}{l}\text { Accurate Identification; } \\
\text { Application Aware } \\
\text { The student identifies } \\
\text { three or more elements } \\
\text { of relevant information } \\
\text { in the chart. Requires } \\
\text { moderate assistance in } \\
\text { locating and applying } \\
\text { information to the case. } \\
\text { Student needs moderate } \\
\text { direct or specific } \\
\text { instruction. }\end{array}$ & $\begin{array}{l}\text { Accurate Identification; } \\
\text { Application Developing } \\
\text { Student identifies at } \\
\text { least } 4 \text { or more } \\
\text { elements of relevant } \\
\text { information in the } \\
\text { chart. Requires } \\
\text { minimal assistance in } \\
\text { locating and applying } \\
\text { relevant information. }\end{array}$ & $\begin{array}{l}\text { Accurate Identification } \\
\text { and Application } \\
\text { The student identifies } \\
\text { all pertinent information } \\
\text { and understands the } \\
\text { meaning with semi- } \\
\text { independence. The } \\
\text { student can analyze } \\
\text { relevance to the case } \\
\text { with intermittent } \\
\text { guidance. }\end{array}$ & $\begin{array}{l}\text { Accurate \& Efficient } \\
\text { The student can identify } \\
\text { and understand the } \\
\text { meaning of all pertinent } \\
\text { information in the chart } \\
\text { and can apply relevance } \\
\text { to the case independently } \\
\text { with consultative } \\
\text { guidance. }\end{array}$ & \begin{tabular}{l}
\multicolumn{1}{c}{ Accurate \& Efficient } \\
The student can \\
independently identify, \\
analyze and report all \\
pertinent information \\
found in the chart \\
relevant to the case. The \\
student operates \\
independently with \\
student initiated \\
assistance observed.
\end{tabular} \\
\hline
\end{tabular}




\begin{tabular}{|c|c|c|c|c|c|c|c|}
\hline Key Elements & Level I & Level II & Level III & Level IV & Level V & Level VI & Level VII \\
\hline $\begin{array}{l}\text { 2. Relates findings from } \\
\text { chart review to normal } \\
\text { and disordered } \\
\text { speech/language/ } \\
\text { swallowing ability to } \\
\text { plan therapeutic } \\
\text { intervention. } \\
\text { Self-Evaluation } \\
\text { Midterm } \\
\text { Final }\end{array}$ & \begin{tabular}{l}
\multicolumn{1}{c|}{ Absent } \\
Student is unfamiliar \\
with norms for effective \\
communication and is \\
unable to identify \\
types/characteristics of \\
disordered \\
communication. The \\
student requires \\
constant direct \\
assistance to identify \\
normal and disordered \\
communication.
\end{tabular} & $\begin{array}{l}\text { Partial Recognition } \\
\text { The student may begin } \\
\text { to recognize the } \\
\text { comparison of norms to } \\
\text { disorders but is unable } \\
\text { to identify } \\
\text { characteristics and } \\
\text { degree of the disorder } \\
\text { without directive. The } \\
\text { student requires direct } \\
\text { assistance in identifying } \\
\text { and comparing deficits } \\
\text { in communication } \\
\text { behaviors as compared } \\
\text { to normals. }\end{array}$ & $\begin{array}{l}\text { Accurate Recognition; } \\
\text { Severity Awareness } \\
\text { The student identifies } \\
\text { primary communication } \\
\text { deficits and has some } \\
\text { knowledge of severity. } \\
\text { The student requires } \\
\text { moderate instruction. }\end{array}$ & \begin{tabular}{l}
\multicolumn{1}{|c}{ Accurate } \\
Recognition; Severity \\
Awareness Developing \\
The student clearly \\
identifies types and \\
severity of \\
communication \\
disorders in relation to \\
normal. However, the \\
student may require \\
specific instruction.
\end{tabular} & $\begin{array}{l}\quad \begin{array}{c}\text { Accurate } \\
\text { Recognition/ }\end{array} \\
\quad \text { Analysis } \\
\text { The student can } \\
\text { identify, analyze } \\
\text { and document } \\
\text { relevance of the } \\
\text { communication } \\
\text { disorder to the } \\
\text { case with semi- } \\
\text { independence and } \\
\text { intermittent } \\
\text { guidance. }\end{array}$ & $\begin{array}{l}\text { Accurate \& Efficient } \\
\text { Recognition/Analysis } \\
\text { The student can } \\
\text { identify, analyze and } \\
\text { document relevance } \\
\text { of the communication } \\
\text { disorder to the case } \\
\text { with consultative } \\
\text { guidance only. }\end{array}$ & $\begin{array}{l}\quad \begin{array}{l}\text { Accurate \& } \\
\text { Efficient }\end{array} \\
\text { The student can } \\
\text { independently } \\
\text { analyze and } \\
\text { clearly document } \\
\text { findings relevant } \\
\text { to the case. The } \\
\text { student operates } \\
\text { independently } \\
\text { with student- } \\
\text { initiated } \\
\text { assistance } \\
\text { observed. }\end{array}$ \\
\hline $\begin{array}{l}\text { 3. Demonstrates } \\
\text { understanding of } \\
\text { relationship of causal } \\
\text { or comorbid } \\
\text { conditions. } \\
\text { Self-Evaluation } \\
\text { Midterm } \\
\text { Final }\end{array}$ & \begin{tabular}{l}
\multicolumn{1}{c|}{ Absent } \\
The student is not \\
familiar with the cause \\
and effect relationship \\
of current or premorbid \\
conditions that \\
contribute to the \\
disordered case. The \\
student requires \\
constant assistance to \\
interpret factors \\
effecting the case.
\end{tabular} & $\begin{array}{l}\text { Identification/Partial } \\
\quad \text { Comprehension } \\
\text { The student can } \\
\text { identify conditions that } \\
\text { may affect the } \\
\text { diagnosis/treatment of } \\
\text { the disorder. However, } \\
\text { student requires } \\
\text { consistent direct } \\
\text { instruction to } \\
\text { comprehend impact on } \\
\text { client's condition. }\end{array}$ & $\begin{array}{l}\text { Accurate } \\
\begin{array}{l}\text { Comprehension/Partial } \\
\text { Application }\end{array} \\
\text { The student understands } \\
\text { basic relevance of } \\
\text { conditions that can } \\
\text { affect the treatment of } \\
\text { the case. The student } \\
\text { needs moderate } \\
\text { instruction to relate and } \\
\text { apply information to } \\
\text { treatment plan. }\end{array}$ & \begin{tabular}{l}
\multicolumn{1}{c}{$\begin{array}{c}\text { Accurate } \\
\text { Comprehension/ } \\
\text { Application }\end{array}$} \\
The student identifies \\
and understands the \\
specific relevance of \\
conditions that affects \\
the treatment of the \\
case. The student \\
requires minimal \\
instruction.
\end{tabular} & $\begin{array}{l}\quad \begin{array}{c}\text { Semi-Independent } \\
\text { Comprehensive }\end{array} \\
\quad \begin{array}{c}\text { Analysis } \\
\text { The student identifies, }\end{array} \\
\text { understands and } \\
\text { analyzes the relevance } \\
\text { of conditions that } \\
\text { affect treatment of the } \\
\text { case with semi- } \\
\text { independence } \\
\text { requiring intermittent } \\
\text { guidance. }\end{array}$ & \begin{tabular}{l}
\multicolumn{1}{c}{$\begin{array}{c}\text { Comprehensive } \\
\text { Analysis and }\end{array}$} \\
$\quad$ Application \\
The student \\
identifies, completely \\
understands and \\
analyzes relevance of \\
conditions that affect \\
treatment of the case \\
with independence \\
requiring consultative \\
guidance only.
\end{tabular} & 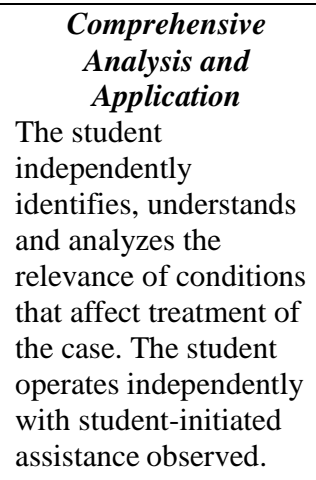 \\
\hline $\begin{array}{l}\text { 4. Devises interview and } \\
\text { probes to generate } \\
\text { hypothesis for EBP. } \\
\text { Self-Evaluation } \\
\text { Midterm } \\
\text { Final }\end{array}$ & \begin{tabular}{l}
\multicolumn{1}{c|}{ Absent } \\
The student is \\
unfamiliar with \\
elements of an effective \\
interview and is unable \\
to formulate a \\
hypothesis based on \\
EBP. The student \\
requires constant \\
assistance.
\end{tabular} & $\begin{array}{l}\text { Partial; Absent } \\
\text { Hypothesis } \\
\text { The student is familiar } \\
\text { with basic elements of } \\
\text { an effective interview } \\
\text { but is unable to } \\
\text { formulate a diagnostic } \\
\text { hypothesis based on } \\
\text { EBP. The student } \\
\text { requires consistent } \\
\text { direct instruction. }\end{array}$ & $\begin{array}{l}\text { Accurate Application; } \\
\text { Emergent Hypothesis } \\
\text { The student applies } \\
\text { necessary elements of } \\
\text { an effective interview } \\
\text { and begins to formulate } \\
\text { hypotheses on which to } \\
\text { base EBP. The student } \\
\text { needs moderate and/or } \\
\text { specific instruction. }\end{array}$ & $\begin{array}{l}\text { Accurate Application } \\
\text { and Hypothesis with } \\
\text { Minimal Assistance } \\
\text { The student applies } \\
\text { necessary elements of } \\
\text { an effective interview } \\
\text { and formulates } \\
\text { hypotheses on which to } \\
\text { base EBP. The student } \\
\text { needs minimal } \\
\text { assistance. }\end{array}$ & \begin{tabular}{l}
\multicolumn{1}{c}{ Semi-Independent } \\
Accurate Application \\
$\quad$ and Hypothesis \\
The student applies \\
necessary elements of \\
an effective interview \\
and is able to \\
formulate a hypothesis \\
based on EBP with \\
semi-independence \\
and intermittent \\
guidance.
\end{tabular} & $\begin{array}{l}\quad \begin{array}{l}\text { Accurate and } \\
\text { Comprehensive }\end{array} \\
\text { The student applies } \\
\text { necessary elements of } \\
\text { an effective interview } \\
\text { and is able to } \\
\text { formulate a } \\
\text { hypothesis based on } \\
\text { EBP independently } \\
\text { with consultative } \\
\text { guidance as needed. }\end{array}$ & $\begin{array}{l}\text { Accurate and } \\
\quad \text { Comprehensive } \\
\text { The student can } \\
\text { independently apply } \\
\text { necessary elements of } \\
\text { an effective interview } \\
\text { and formulate a } \\
\text { hypothesis based on } \\
\text { EBP with student- } \\
\text { initiated assistance } \\
\text { observed. }\end{array}$ \\
\hline
\end{tabular}




\begin{tabular}{|c|c|c|c|c|c|c|c|}
\hline Key Elements & Level I & Level II & Level III & Level IV & Level V & Level VI & Level VII \\
\hline $\begin{array}{l}\text { 5. Determines EBP for } \\
\text { treatment. } \\
\text { Self-Evaluation } \\
\text { Midterm } \\
\text { Final }\end{array}$ & \begin{tabular}{l}
\multicolumn{1}{c|}{ Absent } \\
The student is \\
unfamiliar with and \\
unable to determine \\
appropriate EBP for \\
treatment goals. This \\
requires constant \\
assistance.
\end{tabular} & \begin{tabular}{l}
\multicolumn{1}{c}{ Knowledgeable; } \\
Maximum Assistance \\
The student is familiar \\
but unable to determine \\
appropriate EBP for \\
treatment goals. The \\
student requires \\
consistent direct \\
instruction.
\end{tabular} & $\begin{array}{l}\text { Knowledgeable; } \\
\text { Moderate Assistance } \\
\text { The student begins to } \\
\text { identify appropriate } \\
\text { EBP for treatment } \\
\text { goals with assistance } \\
\text { but requires moderate } \\
\text { and/or specific } \\
\text { instruction. }\end{array}$ & $\begin{array}{l}\quad \text { Knowledgeable; } \\
\text { Minimum Assistance } \\
\text { The student clearly } \\
\text { identifies appropriate } \\
\text { EBP for treatment } \\
\text { goals with specific } \\
\text { assistance. }\end{array}$ & \begin{tabular}{l}
\multicolumn{1}{c}{$\begin{array}{l}\text { Knowledgeable; } \\
\text { Semi-Independent } \\
\text { The student can }\end{array}$} \\
identify appropriate \\
EBP and can apply \\
across most treatment \\
goals with semi- \\
independent and \\
intermittent guidance.
\end{tabular} & $\begin{array}{l}\quad \begin{array}{c}\text { Knowledgeable; } \\
\quad \text { Applies EBP }\end{array} \\
\text { The student can } \\
\text { identify appropriate } \\
\text { EBP and can apply it } \\
\text { across most treatment } \\
\text { goals independently } \\
\text { with consultative } \\
\text { guidance. }\end{array}$ & \begin{tabular}{l}
\multicolumn{1}{c}{$\begin{array}{c}\text { Knowledgeable; } \\
\quad \text { Applies } \boldsymbol{E B P P}\end{array}$} \\
The student can \\
independently apply \\
appropriate EBP for \\
treatment goals. The \\
student operates \\
independently with \\
student-initiated \\
consultative guidance \\
as needed.
\end{tabular} \\
\hline $\begin{array}{l}\text { 6. Writes measurable } \\
\text { treatment goals } \\
\text { Self-Evaluation } \\
\text { Midterm } \\
\text { Final }\end{array}$ & \begin{tabular}{|l|}
\multicolumn{1}{|c|}{ Inaccurate and } \\
\multicolumn{1}{c|}{ Inefficient } \\
Student does not \\
identify individualized \\
treatment goals and/or \\
objectives and does not \\
consult relevant \\
evidence. This student \\
requires constant direct \\
instruction.
\end{tabular} & $\begin{array}{l}\quad \text { Partially Accurate, } \\
\quad \text { Inefficient } \\
\text { Student identifies one } \\
\text { or more areas for } \\
\text { treatment; however, } \\
\text { targeted areas may or } \\
\text { may not be appropriate } \\
\text { to client's needs and } \\
\text { may not be based on } \\
\text { relevant evidence. This } \\
\text { student does not write } \\
\text { measurable treatment } \\
\text { goals and objectives. } \\
\text { This student requires } \\
\text { consistent direct } \\
\text { instruction. }\end{array}$ & \begin{tabular}{l}
\multicolumn{1}{c}{ Accurate with } \\
Moderate Assistance \\
Student identifies one \\
or more appropriate \\
areas for treatment. \\
Requires moderate \\
assistance in writing \\
measurable goals and \\
objectives and/or \\
finding or applying \\
relevant evidence. This \\
student requires \\
moderate specific \\
instruction.
\end{tabular} & $\begin{array}{l}\quad \text { Accurate with } \\
\text { Minimal Assistance } \\
\text { Student identifies one } \\
\text { or more appropriate } \\
\text { areas for treatment. } \\
\text { Requires minimal } \\
\text { assistance in writing } \\
\text { measurable goals and } \\
\text { objectives and/or } \\
\text { finding or applying } \\
\text { relevant evidence. This } \\
\text { student requires direct } \\
\text { or specific instruction. }\end{array}$ & \begin{tabular}{l}
\multicolumn{1}{c}{$\begin{array}{c}\text { Accurate with } \\
\text { Monitoring }\end{array}$} \\
With intermittent \\
guidance, student can \\
write, measurable \\
treatment goals and \\
objectives semi- \\
independently. With \\
intermittent guidance, \\
student can find and \\
evaluate \\
appropriateness of \\
EBP to client. The \\
student operates semi- \\
independently.
\end{tabular} & $\begin{array}{l}\text { Accurate \& Efficient } \\
\text { Appropriate, } \\
\text { measurable treatment } \\
\text { goals and objectives } \\
\text { are developed } \\
\text { efficiently and are } \\
\text { based on EBP. This } \\
\text { student operates } \\
\text { independently with } \\
\text { consultative guidance } \\
\text { as needed. }\end{array}$ & $\begin{array}{l}\text { Accurate \& Efficient } \\
\text { Appropriate, } \\
\text { measurable treatment } \\
\text { goals and objectives are } \\
\text { developed efficiently } \\
\text { and are based on EBP. } \\
\text { This student operates } \\
\text { independently with } \\
\text { student initiated } \\
\text { consultative guidance } \\
\text { as needed. }\end{array}$ \\
\hline $\begin{array}{l}\text { 7. Selects intervention } \\
\text { procedures according } \\
\text { to client's identified } \\
\text { needs } \\
\text { Self-Evaluation } \\
\text { Midterm } \\
\text { Final }\end{array}$ & \begin{tabular}{|l|} 
Inaccurate \& Inefficient \\
Student does not select \\
appropriate intervention \\
procedures in \\
accordance with client's \\
needs. Student does not \\
consult relevant \\
evidence and is \\
unaware of needed \\
procedural \\
modifications and \\
requires constant direct \\
instruction.
\end{tabular} & $\begin{array}{l}\quad \text { Partially Accurate; } \\
\quad \text { Inefficient } \\
\text { Student selects one or } \\
\text { more intervention } \\
\text { procedures; however } \\
\text { these procedures may } \\
\text { not be appropriate to } \\
\text { client's needs or } \\
\text { supported by relevant } \\
\text { evidence. Student } \\
\text { requires consistent } \\
\text { direct instruction to } \\
\text { make appropriate } \\
\text { modifications to } \\
\text { selected intervention } \\
\text { procedures. }\end{array}$ & $\begin{array}{l}\quad \text { Accurate with } \\
\text { Moderate Assistance } \\
\text { Student selects one or } \\
\text { more appropriate } \\
\text { treatment procedures } \\
\text { with some relevant } \\
\text { evidential support. } \\
\text { Student requires } \\
\text { moderate assistance to } \\
\text { make appropriate } \\
\text { procedural } \\
\text { modifications in } \\
\text { accordance with } \\
\text { client's needs. Student } \\
\text { requires direct } \\
\text { instruction less than } \\
\text { 50\% of the time. }\end{array}$ & $\begin{array}{l}\quad \text { Accurate with } \\
\text { Minimal Assistance } \\
\text { Student selects two or } \\
\text { more appropriate } \\
\text { intervention } \\
\text { procedures with } \\
\text { relevant evidential } \\
\text { support. Student } \\
\text { requires minimal } \\
\text { assistance to make } \\
\text { appropriate procedural } \\
\text { modifications in } \\
\text { accordance with } \\
\text { client's needs. } \\
\text { Student requires direct } \\
\text { instruction less than } \\
\text { 25\% of the time. }\end{array}$ & \begin{tabular}{l} 
Semi-Independent; \\
\multicolumn{1}{c}{ Accurate } \\
Student selects two or \\
more appropriate \\
intervention \\
procedures with \\
relevant evidential \\
support. Student \\
intermittently requires \\
intermittent guidance \\
to make procedural \\
modifications in \\
accordance with \\
client's needs. Student \\
operates semi- \\
independently.
\end{tabular} & $\begin{array}{l}\text { Accurate \& Efficient } \\
\text { Student } \\
\text { independently selects } \\
\text { appropriate } \\
\text { intervention } \\
\text { strategies/procedures } \\
\text { with relevant } \\
\text { evidential support in } \\
\text { accordance with } \\
\text { client's needs. } \\
\text { Consultative } \\
\text { guidance is provided } \\
\text { on an as needed basis } \\
\text { for required } \\
\text { procedural } \\
\text { modifications to } \\
\text { intervention } \\
\text { procedures. }\end{array}$ & $\begin{array}{l}\text { Accurate \& Efficient } \\
\text { Student independently } \\
\text { selects appropriate } \\
\text { intervention } \\
\text { strategies/procedures } \\
\text { with relevant evidential } \\
\text { support in accordance } \\
\text { with client's needs. } \\
\text { Student independently } \\
\text { modifies intervention } \\
\text { procedures in } \\
\text { accordance with } \\
\text { client's needs. } \\
\\
\text { Student operates } \\
\text { independently with } \\
\text { student-initiated } \\
\text { consultative guidance } \\
\text { as needed. }\end{array}$ \\
\hline
\end{tabular}




\begin{tabular}{|c|c|c|c|c|c|c|c|}
\hline Key Elements & Level I & Level II & Level III & Level IV & Level V & Level VI & Level VII \\
\hline $\begin{array}{l}\text { 8. Develops plan for data } \\
\text { collection } \\
\text { Self-Evaluation } \\
\text { Midterm } \\
\text { Final }\end{array}$ & \begin{tabular}{|l|} 
Inaccurate \& Inefficient \\
Student is not aware of \\
specific skills that need \\
to be monitored in \\
intervention. The \\
student is unaware of \\
the importance and \\
meaning of data \\
collection as it relates \\
directly to client \\
performance. Student \\
requires constant direct \\
instruction.
\end{tabular} & $\begin{array}{l}\quad \begin{array}{c}\quad \text { Partially Accurate; } \\
\quad \text { Inefficient }\end{array} \\
\text { Student identifies one } \\
\text { or more skills to be } \\
\text { monitored in } \\
\text { intervention; but skills } \\
\text { may not: be relevant to } \\
\text { client's needs, directly } \\
\text { relate to client } \\
\text { performance and/or } \\
\text { reflect realistic } \\
\text { objectives. } \\
\text { Student requires } \\
\text { constant direction. }\end{array}$ & \begin{tabular}{l}
\multicolumn{1}{c|}{ Accurate with } \\
Moderate Assistance \\
Student identifies one \\
or more appropriate \\
skills to be monitored \\
in intervention; \\
however requires \\
moderate assistance in \\
developing data \\
collection plan. Student \\
requires moderate \\
assistance to identify \\
new tools and \\
implement modified \\
adaptations. Student \\
requires direct \\
instruction less than \\
50\% of the time.
\end{tabular} & \begin{tabular}{l}
\multicolumn{1}{c}{ Accurate with } \\
Minimal Assistance \\
Student identifies two \\
or more appropriate \\
skills to be monitored \\
in intervention; but \\
requires minimal \\
assistance in \\
developing data \\
collection plan. \\
Student identifies new \\
tools and/or needed \\
modified adaptations \\
relevant to client \\
needs. \\
Student requires \\
minimal direct or \\
specific instruction \\
from supervisor; less \\
than $25 \%$ of the time.
\end{tabular} & \begin{tabular}{l}
\multicolumn{1}{c}{$\begin{array}{c}\text { Accurate with } \\
\text { Monitoring }\end{array}$} \\
Student identifies two \\
or more appropriate \\
skills to be monitored \\
in intervention semi- \\
independently. Student \\
presents evidence of \\
new tools and/or \\
necessary modified \\
adaptations and \\
develops data \\
collection plan \\
appropriate to client's \\
needs.
\end{tabular} & $\begin{array}{l}\text { Accurate \& Efficient } \\
\text { Student identifies } \\
\text { appropriate skills to } \\
\text { be monitored in } \\
\text { intervention. Student } \\
\text { independently selects } \\
\text { appropriate data } \\
\text { collection including } \\
\text { new tools and/or } \\
\text { needed modified } \\
\text { adaptations relevant } \\
\text { to client's progress. } \\
\text { Consultative } \\
\text { guidance is provided } \\
\text { on an as needed basis. }\end{array}$ & $\begin{array}{l}\text { Accurate \& Efficient } \\
\text { Student identifies } \\
\text { appropriate skills to be } \\
\text { monitored in } \\
\text { intervention. Student } \\
\text { independently selects } \\
\text { appropriate data } \\
\text { collection including } \\
\text { new tools and/or } \\
\text { needed modified } \\
\text { adaptations relevant to } \\
\text { client's progress. } \\
\text { Student operates } \\
\text { independently with } \\
\text { student-initiated } \\
\text { consultative guidance, } \\
\text { as needed. }\end{array}$ \\
\hline \multicolumn{8}{|c|}{ Treatment } \\
\hline $\begin{array}{l}\text { 9. Modifies treatment } \\
\text { room in accordance } \\
\text { with client's needs } \\
\text { with supported } \\
\text { resources } \\
\text { Self-Evaluation } \\
\text { Midterm } \\
\text { Final }\end{array}$ & \begin{tabular}{|l|} 
Absence of Preparation \\
Student is unaware and \\
does not suggest \\
necessary treatment \\
room modifications in \\
accordance with client \\
needs. \\
Student requires \\
constant direct \\
instruction to \\
incorporate relevant \\
factors in order to \\
modify arrangement of \\
treatment environment.
\end{tabular} & $\begin{array}{l}\quad \text { Partially Prepared } \\
\text { Student makes one } \\
\text { modification to } \\
\text { treatment environment; } \\
\text { however modification } \\
\text { may not be appropriate } \\
\text { to client's needs or } \\
\text { supported by relevant } \\
\text { evidence. } \\
\text { Student requires } \\
\text { consistent direct } \\
\text { instruction to make } \\
\text { appropriate } \\
\text { modifications to } \\
\text { treatment environment. }\end{array}$ & 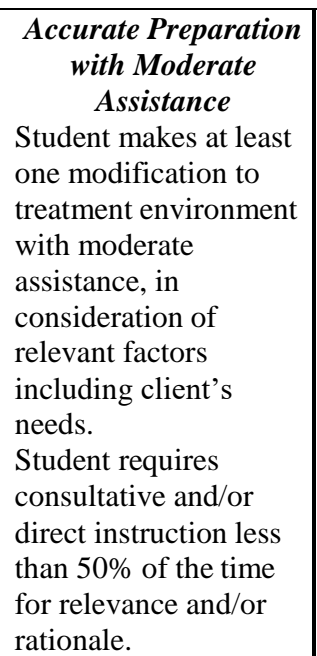 & 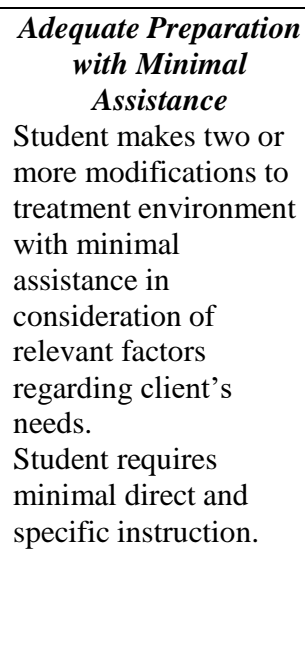 & \begin{tabular}{l}
$\quad$ Efficient \\
\multicolumn{1}{c}{ Preparation with } \\
$\quad$ Monitoring
\end{tabular} & $\begin{array}{l}\text { Efficient \& Thorough } \\
\text { Student makes } \\
\text { appropriate } \\
\text { modifications to } \\
\text { treatment environment } \\
\text { relevant to client's } \\
\text { needs. } \\
\text { Consultative guidance } \\
\text { is provided on an as } \\
\text { needed basis. }\end{array}$ & $\begin{array}{l}\text { Efficient \& Thorough } \\
\text { Student independently } \\
\text { makes appropriate } \\
\text { modifications to } \\
\text { treatment environment } \\
\text { relevant to client's } \\
\text { needs. } \\
\text { Student operates } \\
\text { independently with } \\
\text { student-initiated } \\
\text { consultative guidance, } \\
\text { as needed. }\end{array}$ \\
\hline
\end{tabular}




\begin{tabular}{|c|c|c|c|c|c|c|c|}
\hline Key Elements & Level I & Level II & Level III & Level IV & Level V & Level VI & Level VII \\
\hline $\begin{array}{l}\text { 10. Implements } \\
\text { appropriate } \\
\text { treatment } \\
\text { procedures, models, } \\
\text { prompts and cues. } \\
\text { Self-Evaluation } \\
\text { Midterm } \\
\text { Final }\end{array}$ & \begin{tabular}{|l|}
\multicolumn{1}{|c|}{ Absent } \\
Student does not \\
implement appropriate \\
treatment procedures, \\
models, prompts or \\
cues. \\
Student requires \\
constant direct \\
instruction and \\
modeling of therapeutic \\
strategies; including \\
when to implement \\
strategies during \\
session.
\end{tabular} & \begin{tabular}{l}
\multicolumn{1}{c|}{$\begin{array}{c}\text { Partially Accurate } \\
\text { Inappropriate or } \\
\text { Inconsistent }\end{array}$} \\
Student implements one \\
treatment procedure \\
including models, \\
prompts and cues; but \\
therapeutic procedure \\
may not be appropriate \\
to client's needs, and/or \\
consistently \\
implemented. \\
Student can implement \\
appropriate strategies \\
with ongoing consistent \\
direct and/or specific \\
instruction.
\end{tabular} & $\begin{array}{l}\quad \begin{array}{c}\text { Accurate and } \\
\text { Appropriate } \\
\text { Implementation; }\end{array} \\
\quad \text { Inconsistent } \\
\text { Student implements } \\
\text { one treatment strategy } \\
\text { including models, } \\
\text { prompts and cues with } \\
\text { general direction; but } \\
\text { still requires direct } \\
\text { instruction for } \\
\text { consistent } \\
\text { implementation of } \\
\text { others. Requires } \\
\text { moderate assistance to } \\
\text { make changes based on } \\
\text { client's performance } \\
\text { and/or supervisor } \\
\text { feedback. }\end{array}$ & \begin{tabular}{l}
$\quad \begin{array}{c}\text { Accurate and } \\
\text { Appropriate }\end{array}$ \\
\multicolumn{1}{c}{ Implementation; } \\
$\quad$ Consistent \\
Student consistently \\
implements two or \\
more treatment \\
strategies, models, \\
cues and prompts with \\
general direction; but \\
requires minimal \\
assistance to make \\
changes based on \\
client performance \\
and/or educator \\
feedback.
\end{tabular} & 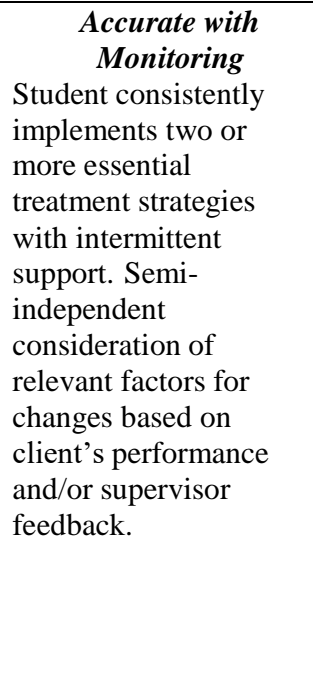 & $\begin{array}{l}\text { Accurate \& Efficient } \\
\text { Student independently } \\
\text { and consistently } \\
\text { implements } \\
\text { appropriate treatment } \\
\text { strategies. Consultative } \\
\text { guidance is provided } \\
\text { on an as needed basis } \\
\text { for implementation of } \\
\text { needed changes based } \\
\text { on client's } \\
\text { performance and/or } \\
\text { educator's feedback. }\end{array}$ & $\begin{array}{l}\text { Accurate \& Efficient } \\
\text { Student independently } \\
\text { and consistently } \\
\text { implements } \\
\text { appropriate treatment } \\
\text { strategies. Student- } \\
\text { initiated consultative } \\
\text { guidance is observed } \\
\text { for implementation of } \\
\text { needed changes based } \\
\text { on client's } \\
\text { performance and/or } \\
\text { supervisor feedback. }\end{array}$ \\
\hline $\begin{array}{l}\text { 11. Collects data } \\
\text { accurately } \\
\text { Self-Evaluation } \\
\text { Midterm } \\
\text { Final }\end{array}$ & \begin{tabular}{|l} 
Inaccurate \& Inefficient \\
Student does not collect \\
data accurately or \\
efficiently. \\
Student requires \\
constant direct \\
instruction for data \\
collection.
\end{tabular} & \begin{tabular}{l}
\multicolumn{1}{c|}{$\begin{array}{c}\text { Partially Accurate; } \\
\quad \text { Inefficient }\end{array}$} \\
Student requires \\
consistent direct and/or \\
specific instruction to \\
accurately collect data. \\
Student's data \\
collection is less than \\
$50 \%$ accurate. Student \\
requires $100 \%$ review \\
of taped session for data \\
reliability.
\end{tabular} & $\begin{array}{l}\quad \text { Accurate with } \\
\text { Moderate Assistance } \\
\text { Student accurately } \\
\text { collects data for one } \\
\text { treatment objective; but } \\
\text { still requires moderate } \\
\text { assistance for tracking } \\
\text { other objectives. } \\
\text { Moderate assistance is } \\
\text { required for } \\
\text { modification of goal, } \\
\text { including cue and } \\
\text { accuracy level relevant } \\
\text { to client's progress. } \\
\text { Review of taped } \\
\text { session may be } \\
\text { required for data } \\
\text { reliability. }\end{array}$ & $\begin{array}{l}\quad \text { Accurate with } \\
\text { Minimal Assistance } \\
\text { Student accurately } \\
\text { collects data for one } \\
\text { treatment objective; } \\
\text { but requires minimal } \\
\text { assistance for tracking } \\
\text { other objectives. } \\
\text { Minimal assistance is } \\
\text { required for } \\
\text { modification of goal, } \\
\text { including cue and } \\
\text { accuracy level relevant } \\
\text { to client's progress. }\end{array}$ & $\begin{array}{l}\quad \quad \begin{array}{l}\text { Accurate with } \\
\quad \text { Monitoring }\end{array} \\
\text { Student accurately } \\
\text { collects data for two or } \\
\text { more objectives. Semi- } \\
\text { independent } \\
\text { consideration of goal } \\
\text { modification including } \\
\text { cueing and accuracy } \\
\text { level relevant to client } \\
\text { progress. }\end{array}$ & $\begin{array}{l}\text { Accurate \& Efficient } \\
\text { Student independently } \\
\text { collects data for all } \\
\text { treatment objectives. } \\
\text { Consultative guidance } \\
\text { is provided on an as } \\
\text { needed basis for goal } \\
\text { modification including } \\
\text { cue and accuracy level } \\
\text { relevant to client's } \\
\text { progress. }\end{array}$ & $\begin{array}{l}\text { Accurate \& Efficient } \\
\text { Student independently } \\
\text { collects data for all } \\
\text { treatment objectives. } \\
\text { Student-initiated } \\
\text { guidance is observed } \\
\text { for goal modification } \\
\text { including cue and } \\
\text { accuracy level relevant } \\
\text { to client's progress. }\end{array}$ \\
\hline
\end{tabular}




\begin{tabular}{|c|c|c|c|c|c|c|c|}
\hline Key Elements & Level I & Level II & Level III & Level IV & Level V & Level VI & Level VII \\
\hline 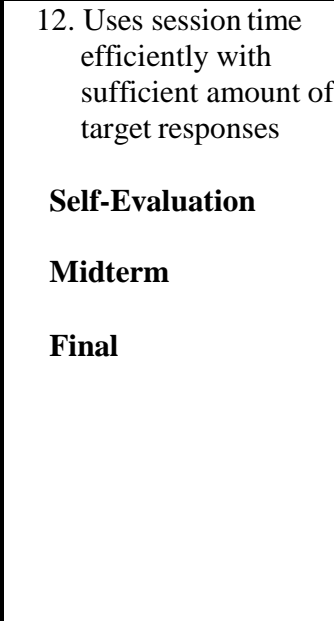 & \begin{tabular}{|l|} 
Inaccurate $\&$ Inefficient \\
Student does not \\
manage session time \\
efficiently as measured \\
by eliciting a sufficient \\
amount of target \\
responses. Session time \\
is wasted due to \\
inefficient number of \\
therapeutic tasks \\
implemented within \\
session time \\
parameters. \\
Student requires \\
constant direct \\
instruction.
\end{tabular} & \begin{tabular}{l}
\multicolumn{1}{c}{ Partially Accurate; } \\
$\quad$ Inefficient \\
Student can address one \\
treatment objective in a \\
timely manner and \\
elicits sufficient target \\
responses from client; \\
however requires direct \\
instruction to address \\
other treatment \\
objectives in an \\
efficient manner.
\end{tabular} & \begin{tabular}{l}
\multicolumn{1}{c}{ Accurate with } \\
Moderate Assistance \\
Student can address \\
one treatment objective \\
in a timely manner; but \\
continues to require \\
moderate assistance in \\
eliciting sufficient \\
amount of target \\
responses for other \\
objectives. \\
Moderate assistance is \\
required for \\
implementing \\
treatment objectives \\
within session time \\
parameters.
\end{tabular} & \begin{tabular}{l}
\multicolumn{1}{c}{ Accurate with } \\
Minimal Assistance \\
Student can address at \\
least two treatment \\
objectives in a timely \\
manner; but continues \\
to require minimal \\
assistance in eliciting \\
sufficient target \\
responses for other \\
objectives. Minimal \\
assistance is required \\
for implementation of \\
treatment objectives \\
within session time \\
parameters.
\end{tabular} & \begin{tabular}{l}
\multicolumn{1}{c}{$\begin{array}{c}\text { Accurate with } \\
\text { Monitoring }\end{array}$} \\
Student can address at \\
least two treatment \\
objectives in a timely \\
manner. Semi- \\
independent \\
consideration of \\
eliciting sufficient \\
amount of target \\
responses relevant to \\
client's limitations \\
and/or needs.
\end{tabular} & $\begin{array}{l}\text { Accurate \& Efficient } \\
\text { Student independently } \\
\text { addresses treatment } \\
\text { objectives in a timely } \\
\text { manner. Consultative } \\
\text { guidance is provided } \\
\text { on an as needed basis } \\
\text { for eliciting sufficient } \\
\text { amount of target } \\
\text { responses relevant to } \\
\text { client's limitations } \\
\text { and/or needs. }\end{array}$ & $\begin{array}{l}\text { Accurate \& Efficient } \\
\text { Student independently } \\
\text { addresses treatment } \\
\text { objectives in a timely } \\
\text { manner. Student- } \\
\text { initiated guidance is } \\
\text { observed for eliciting } \\
\text { sufficient amount of } \\
\text { target responses } \\
\text { relevant to client's } \\
\text { limitations and/or } \\
\text { needs. }\end{array}$ \\
\hline $\begin{array}{l}\text { 13. Anticipates and } \\
\text { reacts to personal } \\
\text { needs of clients; } \\
\text { recognizes cues } \\
\text { from clients (verbal } \\
\text { and nonverbal) } \\
\text { Self-Evaluation } \\
\text { Midterm } \\
\text { Final }\end{array}$ & $\begin{array}{l}\text { Does not anticipate or } \\
\text { react to client's needs } \\
\text { Student is respectful } \\
\text { and establishes initial } \\
\text { rapport. However, } \\
\text { student is more focused } \\
\text { on self needs including } \\
\text { tasks vs. client/family } \\
\text { needs and concerns. } \\
\text { Student does not } \\
\text { recognize client's cues. } \\
\text { Student requires } \\
\text { constant direct } \\
\text { instruction. }\end{array}$ & $\begin{array}{l}\quad \begin{array}{c}\text { Reacts but does not } \\
\text { anticipate client's } \\
\text { needs }\end{array} \\
\text { Student is less focused } \\
\text { on self; is able to react } \\
\text { to client's need but } \\
\text { NOT anticipate } \\
\text { personal- } \\
\text { communicative needs } \\
\text { of client. Student can } \\
\text { recognize needs after } \\
\text { session, not during. } \\
\text { Student requires } \\
\text { consistent direct and/or } \\
\text { specific instruction to } \\
\text { anticipate needs during } \\
\text { session. }\end{array}$ & $\begin{array}{l}\text { Reacts to client's needs; } \\
\text { anticipation aware } \\
\text { Student can } \\
\text { appropriately react to } \\
\text { client's needs during } \\
\text { session; however } \\
\text { requires moderate } \\
\text { assistance in } \\
\text { recognizing client's } \\
\text { verbal cues in order to } \\
\text { anticipate client's and } \\
\text { family's needs. }\end{array}$ & $\begin{array}{l}\begin{array}{c}\text { Consistently reacts to } \\
\quad \text { client's needs; } \\
\quad \text { anticipation } \\
\quad \text { developing }\end{array} \\
\text { Student can recognize } \\
\text { client's needs and react } \\
\text { appropriately during } \\
\text { session; however } \\
\text { requires minimal } \\
\text { assistance to recognize } \\
\text { and anticipate non- } \\
\text { verbal cues and react } \\
\text { appropriately during } \\
\text { session. }\end{array}$ & 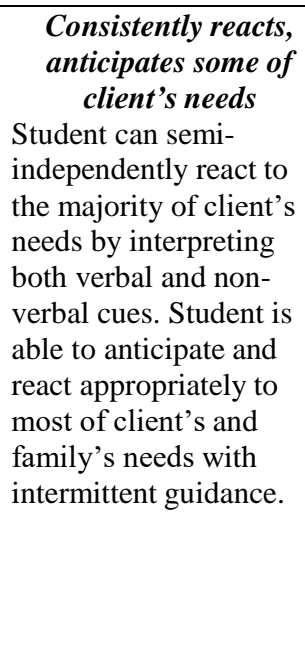 & $\begin{array}{l}\quad \begin{array}{c}\text { Anticipates and } \\
\text { reacts to client's } \\
\text { needs }\end{array} \\
\text { Student independently } \\
\text { anticipates and reacts } \\
\text { to personal needs of a } \\
\text { variety of clients, } \\
\text { recognizing overt and } \\
\text { subtle verbal and non- } \\
\text { verbal cues from client } \\
\text { in session. } \\
\text { Consultative guidance } \\
\text { is provided as needed. }\end{array}$ & $\begin{array}{l}\quad \begin{array}{c}\text { Anticipates and } \\
\text { reacts to client's } \\
\text { needs }\end{array} \\
\text { Student independently } \\
\text { anticipates and reacts } \\
\text { to personal needs of a } \\
\text { variety of clients, } \\
\text { recognizing overt and } \\
\text { subtle verbal and non- } \\
\text { verbal cues from client } \\
\text { in session. Student- } \\
\text { initiated assistance is } \\
\text { observed. }\end{array}$ \\
\hline
\end{tabular}




\begin{tabular}{|c|c|c|c|c|c|c|c|}
\hline Key Elements & Level I & Level II & Level III & Level IV & Level V & Level VI & Level VII \\
\hline $\begin{array}{l}\text { 14. Modifies and adapts } \\
\text { strategies and } \\
\text { activities according } \\
\text { to client needs } \\
\text { Self-Evaluation } \\
\text { Midterm } \\
\text { Final }\end{array}$ & $\begin{array}{l}\quad \begin{array}{c}\text { Does not modify or } \\
\text { adapt strategies or }\end{array} \\
\quad \text { activities } \\
\text { Student does not } \\
\text { recognize need to } \\
\text { modify activities. } \\
\text { Continues with planned } \\
\text { activities even when it } \\
\text { is not appropriate based } \\
\text { on client's response. } \\
\text { Student requires } \\
\text { constant direct } \\
\text { instruction. }\end{array}$ & \begin{tabular}{|l|}
\multicolumn{1}{|c|}{$\begin{array}{c}\text { Modifies activities but } \\
\text { not strategies }\end{array}$} \\
Student recognizes need \\
to modify activities \\
based on client's \\
performance, \\
participation and \\
intervention goals, but \\
selected modifications \\
may not be appropriate \\
or requires direct \\
educator instruction for \\
appropriate \\
modifications. Student \\
requires consistent \\
direct and/or specific \\
instruction to adapt \\
strategies.
\end{tabular} & $\begin{array}{l}\text { Modifies activities but } \\
\quad \text { not strategies with } \\
\text { moderate assistance } \\
\text { Student appropriately } \\
\text { modifies one activity } \\
\text { based on client's } \\
\text { performance, } \\
\text { participation and } \\
\text { intervention goals. } \\
\text { However, student } \\
\text { continues to require } \\
\text { direct instruction to } \\
\text { adapt strategies } 50 \% \text { of } \\
\text { the time. }\end{array}$ & $\begin{array}{l}\quad \text { Modifies activities and } \\
\quad \text { strategies with } \\
\text { minimal assistance } \\
\text { Student appropriately } \\
\text { modifies at least two } \\
\text { activities Student } \\
\text { recognizes need to } \\
\text { modify/adapt but needs } \\
\text { minimum assistance to } \\
\text { understand factors that } \\
\text { influenced the decision. }\end{array}$ & \begin{tabular}{l}
\multicolumn{1}{c}{$\begin{array}{c}\text { Modifies or adapts } \\
\text { some strategies and } \\
\quad \text { activities }\end{array}$} \\
Student can modify \\
some, but not all \\
activities and \\
strategies based on \\
client's \\
performance/participat \\
ion and intervention \\
goals. The student is \\
able to articulate \\
factors that influenced \\
the need to \\
modify/adapt with \\
intermittent guidance.
\end{tabular} & $\begin{array}{l}\quad \begin{array}{l}\text { Modifies and adapts } \\
\quad \text { strategies and } \\
\text { activities }\end{array} \\
\text { Student relates } \\
\text { modifications and } \\
\text { adaptations to the } \\
\text { client's } \\
\text { performance/participati } \\
\text { on and their } \\
\text { intervention goals. } \\
\text { Student is able to } \\
\text { articulate factors that } \\
\text { influenced the need to } \\
\text { modify and adapt. } \\
\text { Student operates } \\
\text { independently with } \\
\text { consultative guidance } \\
\text { provided on an as } \\
\text { needed basis. }\end{array}$ & $\begin{array}{l}\begin{array}{l}\text { Modifies and adapts } \\
\quad \text { strategies and } \\
\text { activities }\end{array} \\
\text { Student relates } \\
\text { modifications and } \\
\text { adaptations to the } \\
\text { client's } \\
\text { performance/participat } \\
\text { ion and their } \\
\text { intervention goals. } \\
\text { Student is able to } \\
\text { articulate factors that } \\
\text { influenced the need to } \\
\text { modify and adapt. } \\
\text { Student operates } \\
\text { independently with } \\
\text { student-initiated } \\
\text { assistance observed. }\end{array}$ \\
\hline \multicolumn{8}{|c|}{ Interpretation Of Therapeutic Intervention } \\
\hline $\begin{array}{l}\text { 15. Reports session data } \\
\text { accurately and } \\
\text { comprehensively } \\
\text { S 10\% } \\
\text { O 30\% } \\
\text { A 30\% } \\
\text { P 15\% } \\
\text { Spelling and } \\
\text { grammar = 15\% } \\
\text { Self-Evaluation } \\
\text { Midterm } \\
\text { Final }\end{array}$ & $\begin{array}{l}\quad \quad \begin{array}{l}\quad \text { Inaccurate } \\
\text { and/or Unclear }\end{array} \\
\text { Student omits data. } \\
\text { Student does not } \\
\text { demonstrate } \\
\text { consistency in data } \\
\text { collection or data are } \\
\text { not accurately reflected } \\
\text { in SOAP note. Student } \\
\text { is dependent on Clinical } \\
\text { Educator for guidance } \\
\text { on how to report data. } \\
\text { This student requires } \\
\text { constant direct } \\
\text { instruction to } \\
\text { conceptualize how data } \\
\text { relate to client's } \\
\text { performance. }\end{array}$ & \begin{tabular}{|l|} 
Partially Accurate, Weak \\
Justification; Narrow \\
Data are reflected in \\
SOAP with errors. \\
Student demonstrates \\
emerging understanding \\
of the meaning of data \\
for specific client. \\
Student requires \\
maximum assistance for \\
reporting client's \\
response to cueing \\
during session and \\
relating to past \\
performance over time. \\
This student requires \\
constant direct \\
instruction to \\
conceptualize how data \\
relate to client's \\
performance.
\end{tabular} & \begin{tabular}{l}
\multicolumn{1}{c}{ Partially Accurate, } \\
Limited Justification; \\
$\quad$ Narrow \\
Data are reflected in \\
SOAP with minor \\
errors. Student \\
demonstrates \\
understanding of data \\
for specific client. \\
Student demonstrates \\
ability to report data; \\
however, moderate \\
assistance is required \\
for accuracy. This \\
student requires \\
consultation and direct \\
instruction to report \\
data which accurately \\
reflects client's \\
performance
\end{tabular} & \begin{tabular}{l}
\multicolumn{1}{c|}{ Accurate, Better } \\
Justification; Narrow \\
Data are reflected \\
accurately in SOAP. \\
Student demonstrates \\
understanding of data \\
for a variety of clients \\
and can report data, \\
including cueing \\
hierarchies. This \\
student requires \\
consultation at times to \\
accurately \\
conceptualize the \\
relationship of \\
therapeutic \\
interventions to data \\
client's progress.
\end{tabular} & 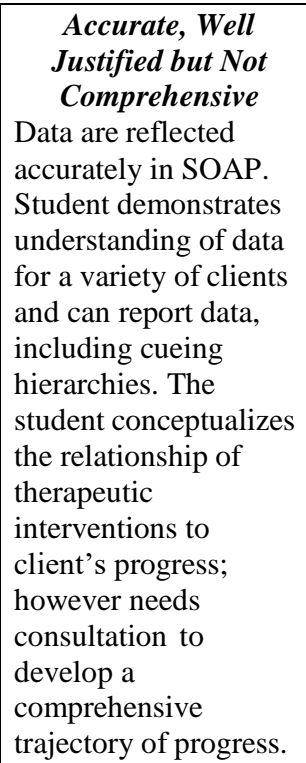 & $\begin{array}{l}\quad \text { Accurate, Well } \\
\quad \text { Justified; } \\
\quad \text { Comprehensive } \\
\text { Data are reflected } \\
\text { accurately in SOAP. } \\
\text { Student demonstrates } \\
\text { understanding of data } \\
\text { for a variety of clients } \\
\text { and can report data, } \\
\text { including cueing } \\
\text { hierarchies. The } \\
\text { student operates } \\
\text { independently for data } \\
\text { reporting with } \\
\text { consultative guidance } \\
\text { as needed. }\end{array}$ & $\begin{array}{l}\quad \text { Accurate, Well } \\
\quad \text { Justified; } \\
\quad \text { Comprehensive } \\
\text { Data are reflected } \\
\text { accurately in SOAP. } \\
\text { Student demonstrates } \\
\text { understanding of data } \\
\text { for a variety of clients } \\
\text { and can report data, } \\
\text { including cueing } \\
\text { hierarchies. The } \\
\text { student operates } \\
\text { independently for data } \\
\text { reporting with self- } \\
\text { initiated consultative } \\
\text { guidance as needed. }\end{array}$ \\
\hline
\end{tabular}




\begin{tabular}{|c|c|c|c|c|c|c|c|}
\hline Key Elements & Level I & Level II & Level III & Level IV & Level V & Level VI & Level VII \\
\hline $\begin{array}{l}\text { 16. Formulates } \\
\text { accurate analysis } \\
\text { of therapeutic } \\
\text { intervention } \\
\text { Self-Evaluation } \\
\text { Midterm } \\
\text { Final }\end{array}$ & \begin{tabular}{|l|}
\multicolumn{1}{|c|}{ Absent } \\
Synthesis/Interpretation \\
Analysis includes \\
irrelevant information \\
and/or interpretation of \\
data/client's \\
performance is omitted. \\
Plan is missing \\
detail/individualization. \\
SOAP includes typos \\
and grammatical errors. \\
This student requires \\
constant direct \\
instruction.
\end{tabular} & \begin{tabular}{|l|}
\multicolumn{1}{|c|}{ Partial } \\
Synthesis/Interpretation; \\
Inappropriate Detail, \\
\multicolumn{1}{c|}{ Errors } \\
Analysis includes both \\
deficient and irrelevant \\
data about activity \\
and/or > two irrelevant \\
details. Student \\
includes at least one \\
rationale or \\
interpretation of client's \\
performance, but \\
requires assistance for \\
additional \\
interpretation. Plan is \\
missing detail but \\
student can generate \\
details with maximum \\
assistance from Clinical \\
Educator. SOAP \\
includes spelling errors, \\
typos or grammatical \\
errors. This student \\
requires constant direct \\
instruction.
\end{tabular} & \begin{tabular}{|l}
$\begin{array}{c}\text { Partial } \\
\text { Synthesis/Interpretation; } \\
\text { Appropriate Detail, } \\
\text { Errors }\end{array}$ \\
Analysis is void of \\
irrelevant information. \\
Student provides \\
analysis of client's \\
performance for current \\
session; however, \\
moderate assistance is \\
required for analysis \\
across multiple \\
sessions/longer time \\
frame (month or \\
semester). Plan includes \\
relevant and \\
individualized detail; \\
however, with \\
consultation from \\
Clinical Educator, \\
details demonstrate \\
reflection on client's \\
performance and \\
strategies/changes to \\
implement in next \\
session/future. \\
Occasional spelling \\
errors/typos evident. \\
This student requires \\
direct and specific \\
instruction.
\end{tabular} & \begin{tabular}{l}
\multicolumn{1}{c|}{ Complete } \\
Synthesis/Interpretation \\
$\quad$ but Narrow \\
Analysis of client's \\
performance is \\
accurate; however, \\
student requires \\
guidance from Clinical \\
Educator to address \\
novel situations (e.g., \\
cued responses, etc.). \\
Plan includes relevant \\
and individualized \\
detail. Infrequent \\
spelling errors/typos \\
evident. This student \\
requires minimum \\
assistance.
\end{tabular} & $\begin{array}{l}\text { Complete Synthesis } \\
\quad \text { Comprehensive } \\
\text { Interpretations } \\
\text { Analysis of client's } \\
\text { performance is } \\
\text { accurate, and with } \\
\text { intermittent guidance, } \\
\text { reflects relationship to } \\
\text { feedback, cueing } \\
\text { and/or targeted } \\
\text { strategies. Plan } \\
\text { includes relevant and } \\
\text { individualized detail. } \\
\text { No spelling } \\
\text { errors/typos evident. } \\
\text { The student is semi- } \\
\text { independent requiring } \\
\text { intermittent } \\
\text { instruction. }\end{array}$ & \begin{tabular}{l}
\multicolumn{1}{c}{$\begin{array}{c}\text { Comprehensive } \\
\text { Across Caseload }\end{array}$} \\
Analysis of client's \\
performance accurately \\
reflects relationship to \\
feedback, cueing \\
and/or targeted \\
strategies. Plan \\
includes relevant and \\
individualized detail. \\
No spelling \\
errors/typos evident. \\
The student is \\
independent with \\
consultative guidance \\
as needed.
\end{tabular} & \begin{tabular}{l}
\multicolumn{1}{c}{$\begin{array}{c}\text { Comprehensive } \\
\text { Across Caseload }\end{array}$} \\
Analysis of client's \\
performance \\
accurately reflects \\
relationship to \\
feedback, cueing \\
and/or targeted \\
strategies. Plan \\
includes relevant and \\
individualized detail. \\
No spelling \\
errors/typos evident. \\
The student is \\
independent with \\
student-initiated \\
consultation as \\
needed.
\end{tabular} \\
\hline
\end{tabular}




\begin{tabular}{|c|c|c|c|c|c|c|c|}
\hline Key Elements & Level I & Level II & Level III & Level IV & Level V & Level VI & Level VII \\
\hline $\begin{array}{l}\text { 17. Identifies and refers } \\
\text { clients for services } \\
\text { as appropriate } \\
\text { Self-Evaluation } \\
\text { Midterm } \\
\text { Final }\end{array}$ & \begin{tabular}{l}
\multicolumn{1}{c|}{ Absent } \\
Student is dependent on \\
clinical educator to \\
identify areas of \\
concern for client \\
and/or unaware of \\
services available to \\
refer client/caregiver \\
when appropriate. This \\
student requires \\
constant direct \\
instruction.
\end{tabular} & $\begin{array}{l}\text { Partially Appropriate } \\
\text { Student is able to } \\
\text { identify one to two } \\
\text { areas of concern and } \\
\text { connect concern to at } \\
\text { least one appropriate } \\
\text { referral. This student } \\
\text { needs assistance to } \\
\text { identify new concerns } \\
\text { for a variety of clients } \\
\text { but understands the } \\
\text { need for outside } \\
\text { referrals. This student } \\
\text { requires consistent } \\
\text { direct instruction. }\end{array}$ & $\begin{array}{l}\text { Appropriate but Vague } \\
\text { and Narrow } \\
\text { Student is able to } \\
\text { identify relevant areas } \\
\text { of concern for client } \\
\text { and makes appropriate } \\
\text { referrals with minimum } \\
\text { support for } \\
\text { identification but } \\
\text { moderate support for } \\
\text { available connections } \\
\text { to community } \\
\text { resources/referrals. } \\
\text { This student requires } \\
\text { moderate direct } \\
\text { instruction. }\end{array}$ & $\begin{array}{l}\text { Appropriate, Detailed } \\
\quad \text { but Narrow } \\
\text { Student demonstrates } \\
\text { proficiency in } \\
\text { identifying areas of } \\
\text { concern for clients. } \\
\text { Additional resources, } \\
\text { unique to a particular } \\
\text { population, may be } \\
\text { provided by Clinical } \\
\text { Educator to augment } \\
\text { referrals. This student } \\
\text { completes necessary } \\
\text { record keeping for } \\
\text { referral in a timely } \\
\text { manner. }\end{array}$ & $\begin{array}{l}\text { Appropriate, Detailed, } \\
\quad \text { Pro-Active } \\
\text { Student is semi- } \\
\text { independent in } \\
\text { demonstrating } \\
\text { proficiency in } \\
\text { identifying concerns } \\
\text { for clients. Student } \\
\text { seeks intermittent } \\
\text { guidance from Clinical } \\
\text { Educator to add to } \\
\text { referral } \\
\text { recommendations as } \\
\text { needed. }\end{array}$ & $\begin{array}{l}\text { Appropriate, Detailed } \\
\quad \text { Comprehensive } \\
\text { Student accurately } \\
\text { identifies areas of } \\
\text { concern for a variety of } \\
\text { clients across disorders } \\
\text { and independently } \\
\text { identifies referrals } \\
\text { from a variety of } \\
\text { sources independently } \\
\text { with consultative } \\
\text { guidance as needed. }\end{array}$ & \begin{tabular}{l} 
Appropriate, Detailed \\
\multicolumn{1}{c}{ Comprehensive } \\
Student accurately \\
identifies areas of \\
concern for a variety \\
of clients across \\
disorders. Student \\
independently \\
identifies referrals \\
from a variety of \\
sources with student- \\
initiated consultative \\
guidance as needed.
\end{tabular} \\
\hline $\begin{array}{l}\text { 18. Completes } \\
\text { administrative } \\
\text { functions (billing } \\
\text { sheets, treatment } \\
\text { log, etc.) } \\
\text { Self-Evaluation } \\
\text { Midterm } \\
\text { Final }\end{array}$ & \begin{tabular}{l}
\multicolumn{1}{c|}{ Absent } \\
Student does not \\
complete billing sheets \\
or chart documentation \\
without direction from \\
clinical educator. \\
Student unsure of \\
process, necessary \\
information and \\
exhibits little follow \\
through related to \\
admin functions. This \\
student requires direct \\
instruction.
\end{tabular} & $\begin{array}{l}\text { Inconsistent and/or } \\
\quad \text { Inaccurate } \\
\text { Student understands } \\
\text { process for billing } \\
\text { sheets, treatment log, } \\
\text { etc. however is } \\
\text { inconsistent in } \\
\text { execution of such } \\
\text { functions. Requires } \\
\text { direct instruction from } \\
\text { clinical educator to } \\
\text { ensure follow through } \\
\text { or accuracy. This } \\
\text { student requires direct } \\
\text { instruction. }\end{array}$ & $\begin{array}{l}\text { Accurate/Timely with } \\
\text { Moderate Assistance } \\
\text { Student understands } \\
\text { process for billing } \\
\text { sheets/treatment logs } \\
\text { and completes as } \\
\text { needed; however, } \\
\text { student requires } \\
\text { moderate assistance } \\
\text { from Clinical Educator } \\
\text { for new situations, } \\
\text { clients or diagnoses. } \\
\text { This student requires } \\
\text { direct instruction. }\end{array}$ & $\begin{array}{l}\text { Accurate, Timely with } \\
\text { Minimal Assistance } \\
\text { Student understands } \\
\text { process for billing } \\
\text { sheets/treatment logs } \\
\text { and completes as } \\
\text { required across variety } \\
\text { of diagnoses and } \\
\text { situations with minimal } \\
\text { assistance. }\end{array}$ & \begin{tabular}{l}
\multicolumn{1}{c}{$\begin{array}{c}\text { Accurate, Timely } \\
\quad \text { with Semi- }\end{array}$} \\
$\quad$ Independence \\
Student initiates \\
billing \\
sheets/treatment logs \\
as required with \\
efficiency by \\
consulting own copy \\
of ICD-9 listing. \\
Student is semi- \\
independent; \\
intermittent guidance \\
provided as needed.
\end{tabular} & \begin{tabular}{l}
\multicolumn{1}{c}{$\begin{array}{c}\text { Accurate, Timely } \\
\quad \text { Ethical }\end{array}$} \\
Student initiates billing \\
sheets/treatment logs \\
as required. Student is \\
independent and \\
accurate with \\
consultation as needed.
\end{tabular} & \begin{tabular}{|l}
\multicolumn{1}{c}{$\begin{array}{c}\text { Accurate, Timely, } \\
\quad \text { Ethical }\end{array}$} \\
Student initiates \\
billing \\
sheets/treatment logs \\
as required by facility \\
or entity. Student is \\
independent and \\
accurate with student- \\
initiated consultation \\
observed.
\end{tabular} \\
\hline
\end{tabular}




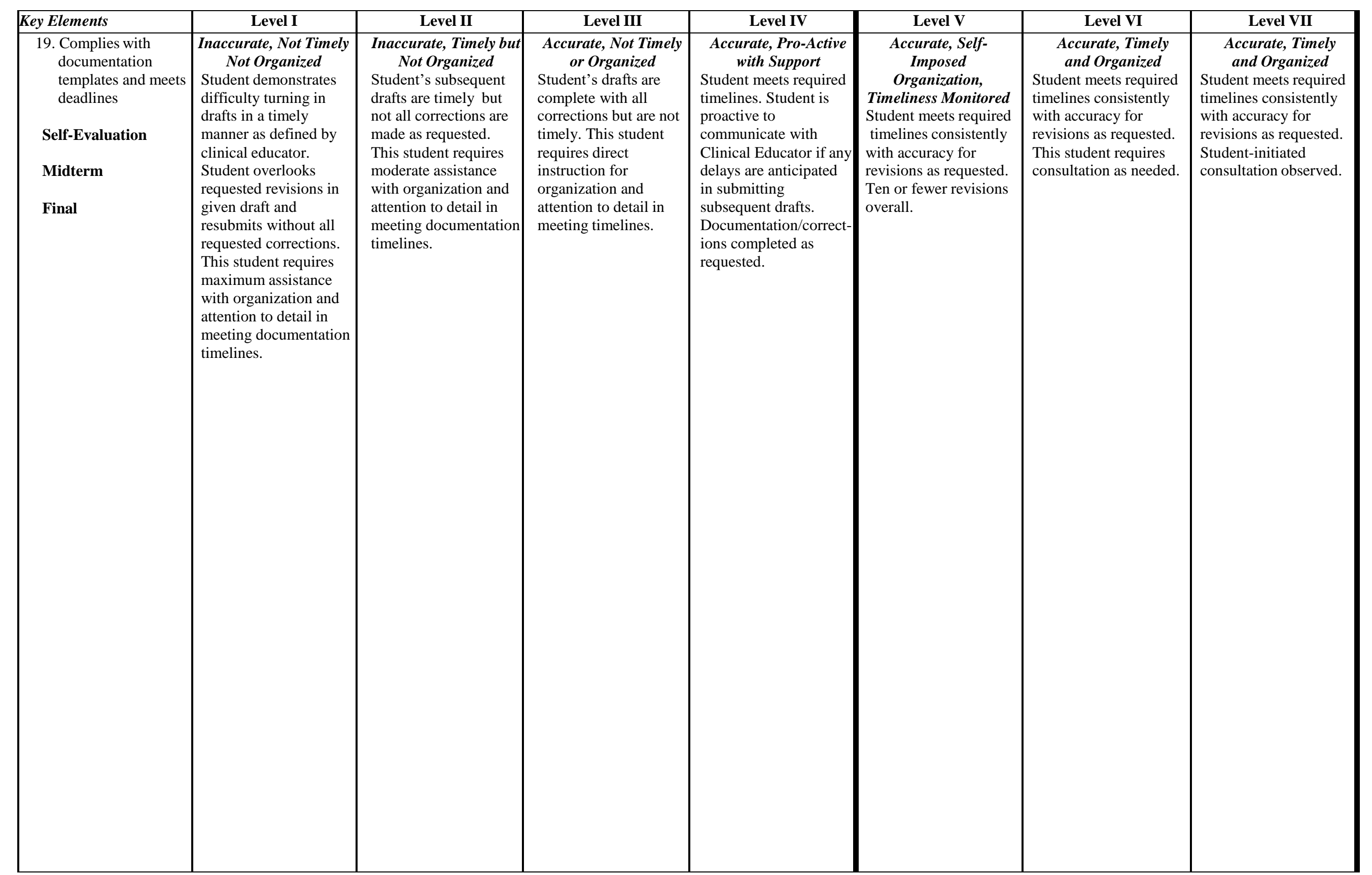


Teaching and Learning in Communication Sciences \& Disorders, Vol. 2 [2018], Iss. 2, Art. 7

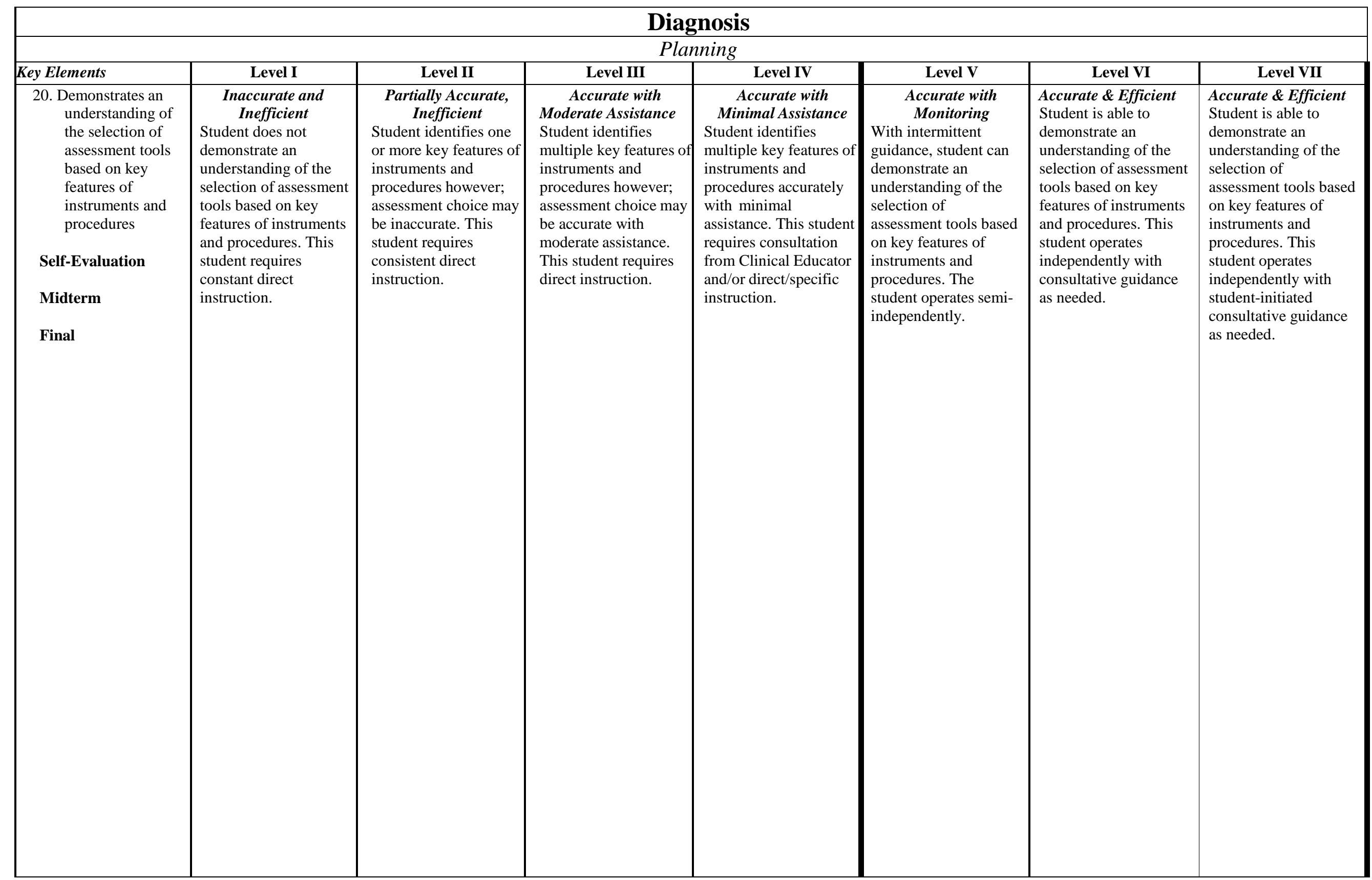




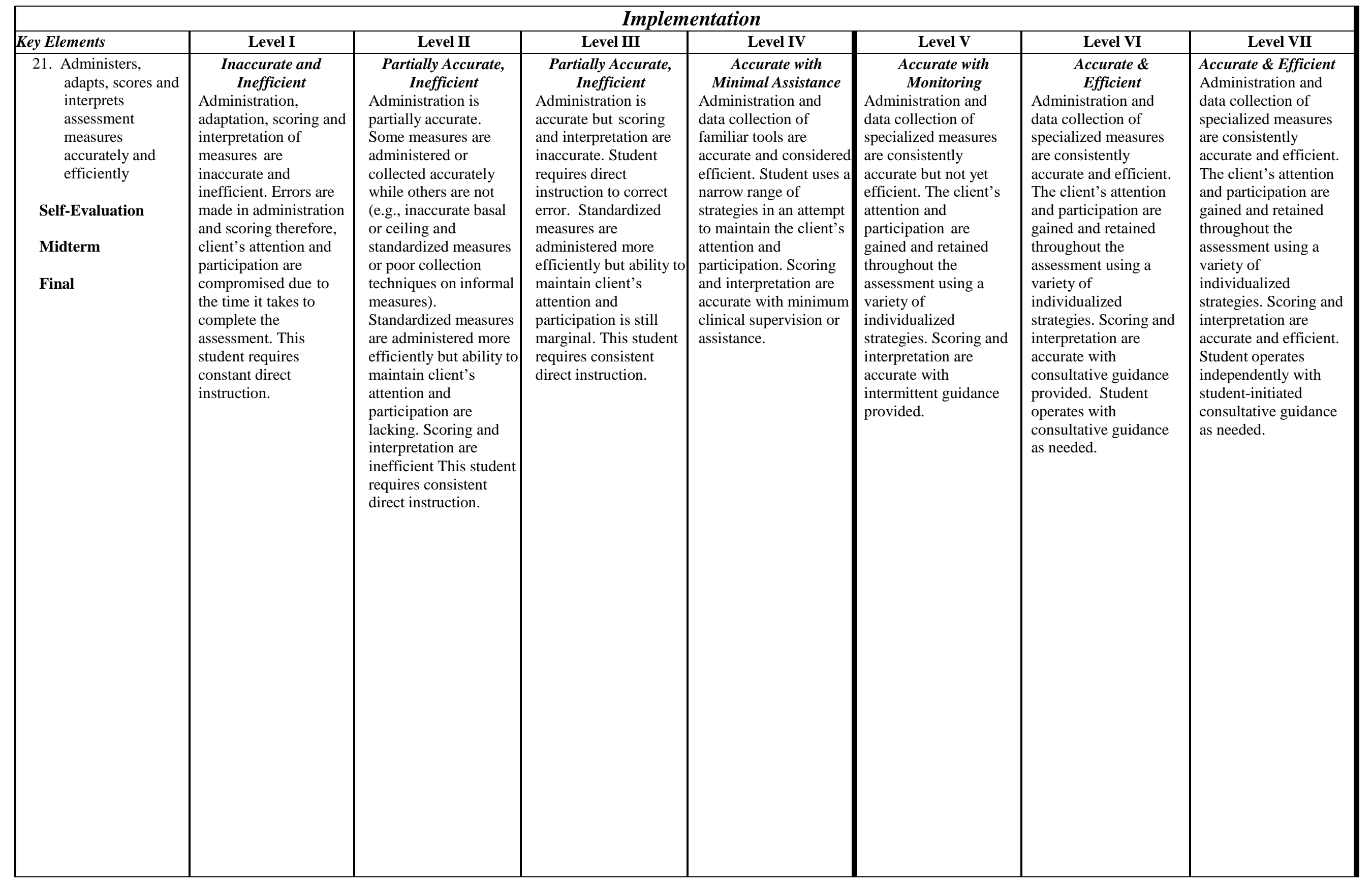


Teaching and Learning in Communication Sciences \& Disorders, Vol. 2 [2018], Iss. 2, Art. 7

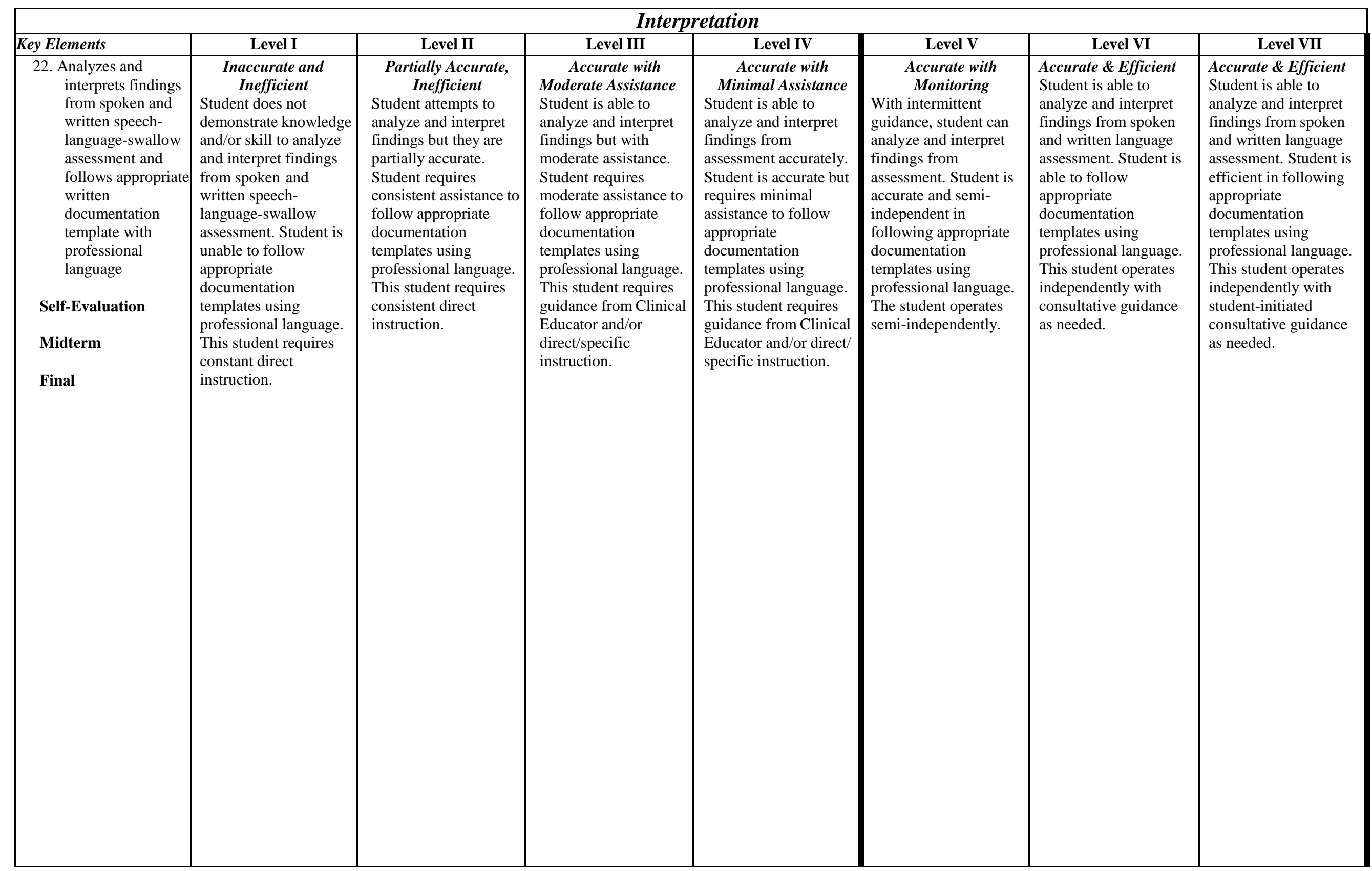




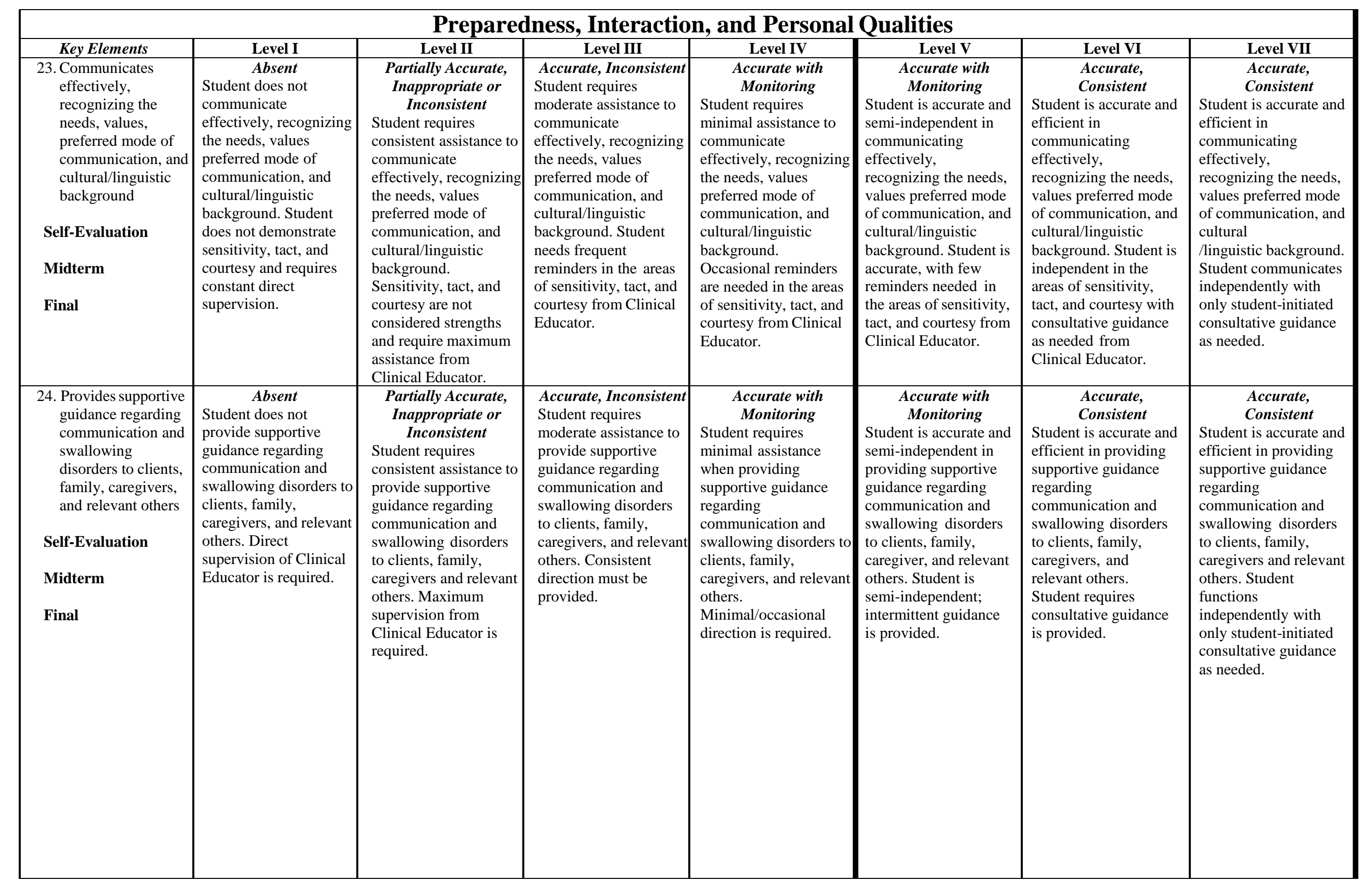




\begin{tabular}{|c|c|c|c|c|c|c|c|}
\hline Key Elements & Level I & Level II & Level III & Level IV & Level V & Level VI & Level VII \\
\hline $\begin{array}{l}\begin{array}{l}\text { 25. Collaborates with } \\
\text { other professionals } \\
\text { in case management }\end{array} \\
\text { Self-Evaluation } \\
\text { Midterm } \\
\text { Final }\end{array}$ & \begin{tabular}{l}
\multicolumn{1}{c|}{ Absent } \\
Unaware of the role of \\
collaboration with other \\
professionals in case \\
management. Constant \\
support required.
\end{tabular} & \begin{tabular}{l}
\multicolumn{1}{c|}{ Partially Aware, } \\
maximum Assistance \\
Recognizes the need \\
for collaboration with \\
other professionals in \\
some aspects of case \\
management. \\
Collaboration initiated \\
by Clinical Educator.
\end{tabular} & $\begin{array}{l}\text { Aware, Inconsistent } \\
\text { Moderate Assistance } \\
\text { Recognizes the need for } \\
\text { collaboration with other } \\
\text { professionals in the } \\
\text { majority of aspects of } \\
\text { case management, with } \\
\text { supervisory support.to } \\
\text { determine scope. }\end{array}$ & \begin{tabular}{l}
\multicolumn{1}{c}{ Aware, Consistent } \\
Minimum Assistance \\
Recognizes the need for \\
collaboration with other \\
professionals in all \\
aspects of case \\
management with \\
minimal Clinical \\
Educator support.
\end{tabular} & $\begin{array}{l}\quad \begin{array}{c}\text { Consistent, Semi- } \\
\quad \text { Independent }\end{array} \\
\text { Recognizes the need } \\
\text { for collaboration with } \\
\text { other professionals } \\
\text { across settings in all } \\
\text { aspects of case } \\
\text { management with } \\
\text { marginal guidance. }\end{array}$ & \begin{tabular}{l}
\multicolumn{1}{c}{$\begin{array}{c}\text { Effective, Self- } \\
\quad \text { Monitors }\end{array}$} \\
Recognizes the need \\
for collaboration with \\
other professionals and \\
implements across \\
settings in all aspects \\
of case management \\
with little to no \\
support.
\end{tabular} & $\begin{array}{l}\quad \text { Effective, Self- } \\
\quad \text { Initiates } \\
\text { Independently } \\
\text { recognizes the need } \\
\text { for collaboration with } \\
\text { other professionals and } \\
\text { consistently } \\
\text { implements across } \\
\text { settings in all aspects } \\
\text { of case management } \\
\text { with self-initiated } \\
\text { consultative guidance } \\
\text { when needed. }\end{array}$ \\
\hline $\begin{array}{l}\text { 26. Displays effective } \\
\text { oral communication } \\
\text { with client, family, } \\
\text { or other } \\
\text { professionals } \\
\text { Self-Evaluation } \\
\text { Midterm } \\
\text { Final }\end{array}$ & \begin{tabular}{l|}
\multicolumn{1}{|c|}{ Inappropriate } \\
Inappropriate \\
professional \\
communication across \\
settings. Does not \\
modify terminology \\
and/or amount of \\
information based on \\
individual's background \\
and needs. \\
Constant support \\
required.
\end{tabular} & \begin{tabular}{l}
\multicolumn{1}{c|}{ Inconsistent, } \\
Maximum Assistance \\
Rarely \\
modifies terminology \\
and/or amount of \\
information based on \\
individual's \\
background and needs. \\
Constant support \\
required.
\end{tabular} & $\begin{array}{l}\quad \begin{array}{l}\text { Inconsistent, Moderate } \\
\text { Assistance }\end{array} \\
\text { Inconsistently } \\
\text { appropriate with } \\
\text { professional } \\
\text { communication with a } \\
\text { variety of } \\
\text { individuals (e.g., client, } \\
\text { family, other } \\
\text { professionals). } \\
\text { Moderate assistance } \\
\text { needed for students to } \\
\text { modify terminology } \\
\text { and/or amount of } \\
\text { information based } \\
\text { on individual's } \\
\text { background. }\end{array}$ & \begin{tabular}{l}
\multicolumn{1}{c}{ Consistent, Minimum } \\
$\quad$ Assistance \\
Demonstrates the \\
ability to modify \\
terminology \\
and/or amount of \\
information based \\
on individual's \\
background and \\
needs with minimal \\
support.
\end{tabular} & \begin{tabular}{l}
\multicolumn{1}{c}{$\begin{array}{c}\text { Consistent, Semi- } \\
\text { Independent }\end{array}$} \\
Appropriate \\
professional \\
communication with a \\
variety of \\
individuals (e.g., \\
client, family, \\
other professionals) \\
most of the \\
time. Modifies \\
terminology and/or \\
amount of information \\
based on \\
individual's \\
background and needs \\
with support. Student \\
is semi-independent \\
with Clinical Educator \\
monitoring.
\end{tabular} & \begin{tabular}{l}
\multicolumn{1}{c}{$\begin{array}{c}\text { Effective, Self- } \\
\quad \text { Monitors }\end{array}$} \\
Appropriate \\
professional \\
communication with a \\
variety of \\
individuals (e.g., \\
client, family, \\
other professionals) \\
almost all of the \\
time. Modifies \\
terminology and/or \\
amount of information \\
based on individual's \\
background and needs \\
little to no support.
\end{tabular} & $\begin{array}{l}\quad \text { Effective, Self- } \\
\quad \text { Initiates } \\
\text { Consistent appropriate } \\
\text { professional } \\
\text { communication with a } \\
\text { variety of } \\
\text { individuals (e.g., } \\
\text { client, family, other } \\
\text { professionals). } \\
\text { Independently } \\
\text { modifies terminology } \\
\text { and/or amount of } \\
\text { information based on } \\
\text { individuals' } \\
\text { background and needs. }\end{array}$ \\
\hline $\begin{array}{l}\text { 27. Adheres to the } \\
\text { ASHA Code of } \\
\text { Ethics and conducts } \\
\text { him or herself in a } \\
\text { professional, ethical } \\
\text { manner } \\
\text { Self-Evaluation } \\
\text { Midterm } \\
\text { Final }\end{array}$ & \begin{tabular}{l}
\multicolumn{1}{c|}{ Unaware } \\
Student unfamiliar with \\
ASHA Code of Ethics \\
and how it applies to \\
clinical interaction.
\end{tabular} & \begin{tabular}{l}
\multicolumn{1}{c|}{ Breech of Ethics } \\
Student may have \\
rudimentary knowledge \\
but does not follow \\
through in all aspects.
\end{tabular} & \begin{tabular}{l}
\multicolumn{1}{c|}{$\begin{array}{c}\text { Breech of Ethics; } \\
\quad \text { Adherence }\end{array}$} \\
Student's remediation \\
of a breech in the \\
ethical standards is met \\
as established. Student \\
can identify elements \\
of the ASHA Code of \\
Ethics but requires \\
supervision.
\end{tabular} & \begin{tabular}{l}
\multicolumn{1}{c}{ Adherence } \\
Student engages in \\
discussion of ethical \\
issues with supervisor \\
to determine best \\
practice.
\end{tabular} & $\begin{array}{l}\quad \text { Adherence; Self- } \\
\quad \text { Monitors } \\
\text { Student engages in } \\
\text { ethical decision } \\
\text { making semi- } \\
\text { independently with } \\
\text { Clinical Educator } \\
\text { monitoring. }\end{array}$ & \begin{tabular}{l}
\multicolumn{1}{c}{ Adherence; Self- } \\
$\quad$ Monitors \\
Student applies ethical \\
decision-making and \\
engages in discussion \\
of ethical issues with \\
consultative guidance.
\end{tabular} & 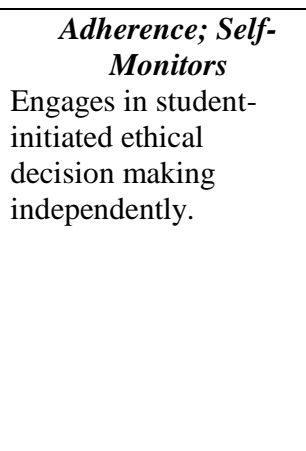 \\
\hline
\end{tabular}




\begin{tabular}{|c|c|c|c|c|c|c|c|}
\hline Key Elements & Level I & Level II & Level III & Level IV & Level V & Level VI & Level VII \\
\hline $\begin{array}{l}\text { 28. Abides by } \\
\text { HIPAA Standards } \\
\text { Self-Evaluation } \\
\text { Midterm } \\
\text { Final }\end{array}$ & \begin{tabular}{l}
\multicolumn{1}{c|}{ Unaware } \\
Inappropriate \\
professional \\
communication across \\
settings. Does not \\
modify terminology \\
and/or amount of \\
information based on \\
individual's background \\
and needs. \\
Constant support \\
required.
\end{tabular} & $\begin{array}{l}\quad \text { Partial Knowledge } \\
\text { Rarely modifies } \\
\text { terminology and/or } \\
\text { amount of } \\
\text { information based } \\
\text { on individual's } \\
\text { background and } \\
\text { needs. Constant } \\
\text { support required. }\end{array}$ & $\begin{array}{l}\text { Knowledge; Adherence } \\
\text { Inconsistently } \\
\text { appropriate with } \\
\text { professional } \\
\text { communication } \\
\text { with a variety of } \\
\text { individuals (e.g., } \\
\text { client, family, other } \\
\text { professionals). } \\
\text { Modifies } \\
\text { terminology } \\
\text { and/or amount of } \\
\text { information based } \\
\text { on individual's } \\
\text { background and } \\
\text { needs with consistent } \\
\text { support. }\end{array}$ & $\begin{array}{l}\quad \text { Adherence } \\
\text { Demonstrates the } \\
\text { ability to modify } \\
\text { terminology } \\
\text { and/or amount of } \\
\text { information based } \\
\text { on individual's } \\
\text { background } \\
\text { with Clinical Educator } \\
\text { support. }\end{array}$ & $\begin{array}{l}\quad \begin{array}{l}\text { Adherence; with } \\
\quad \text { Monitoring }\end{array} \\
\text { Appropriate } \\
\text { professional } \\
\text { communication with a } \\
\text { variety of } \\
\text { individuals (e.g., } \\
\text { client, family, } \\
\text { other professionals) } \\
\text { most of the } \\
\text { time. Modifies } \\
\text { terminology and/or } \\
\text { amount of information } \\
\text { based on } \\
\text { individual's } \\
\text { background with } \\
\text { Clinical Educator } \\
\text { monitoring. }\end{array}$ & $\begin{array}{l}\quad \begin{array}{c}\text { Adherence; Self- } \\
\quad \text { Monitors }\end{array} \\
\text { Appropriate } \\
\text { professional } \\
\text { communication with a } \\
\text { variety of } \\
\text { individuals (e.g., } \\
\text { client, family, } \\
\text { other professionals) } \\
\text { almost all of the } \\
\text { time. Modifies } \\
\text { terminology and/or } \\
\text { amount of information } \\
\text { based on individual's } \\
\text { background and needs } \\
\text { with educator } \\
\text { monitoring. }\end{array}$ & $\begin{array}{l}\quad \begin{array}{c}\text { Adherence; Self- } \\
\quad \text { Monitors }\end{array} \\
\text { Consistent appropriate } \\
\text { professional } \\
\text { communication with a } \\
\text { variety of } \\
\text { individuals (e.g., } \\
\text { client, family, other } \\
\text { professionals). } \\
\text { Consistently } \\
\text { independently } \\
\text { modifies terminology } \\
\text { and/or amount of } \\
\text { information based } \\
\text { on individuals' } \\
\text { background and needs. }\end{array}$ \\
\hline
\end{tabular}

